THE INTERNATIONAL

REVIEW OF RESEARCH IN

OPEN AND DISTANCE LEARNING

\title{
Footprints of Emergence
}
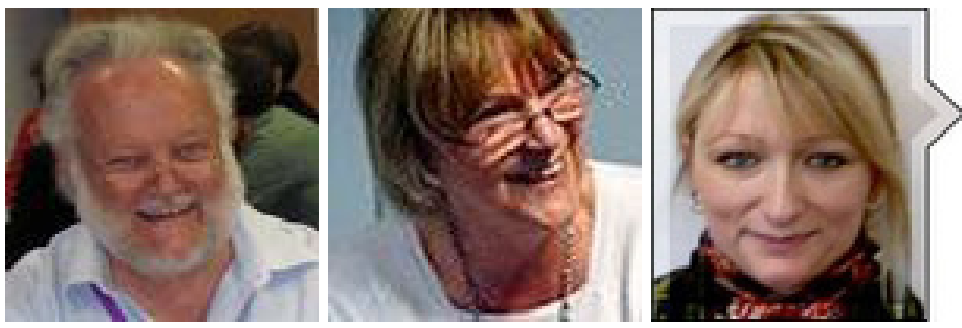

Roy Trevor Williams ${ }^{1}$, Jenny Mackness ${ }^{2}$, and Simone Gumtau ${ }^{1}$ 'University of Portsmouth, United Kingdom, ${ }^{2}$ Independent Consultant, United Kingdom

\section{Abstract}

It is ironic that the management of education has become more closed while learning has become more open, particularly over the past 10-20 years. The curriculum has become more instrumental, predictive, standardized, and micro-managed in the belief that this supports employability as well as the management of educational processes, resources, and value. Meanwhile, people have embraced interactive, participatory, collaborative, and innovative networks for living and learning. To respond to these challenges, we need to develop practical tools to help us describe these new forms of learning which are multivariate, self-organised, complex, adaptive, and unpredictable. We draw on complexity theory and our experience as researchers, designers, and participants in open and interactive learning to go beyond conventional approaches. We develop a $3 \mathrm{D}$ model of landscapes of learning for exploring the relationship between prescribed and emergent learning in any given curriculum. We do this by repeatedly testing our descriptive landscapes (or footprints) against theory, research, and practice across a range of case studies. By doing this, we have not only come up with a practical tool which can be used by curriculum designers, but also realised that the curriculum itself can usefully be treated as emergent, depending on the dynamics between prescribed and emergent learning and how the learning landscape is curated.

Keywords: Emergence; prescribed; self-organization; footprints; topographies; curriculum; design; curation; co-evolution 


\section{Introduction}

The past five years have seen the blossoming of open, online courses and networked learning. Some courses are freely available on the Web and attract large numbers of participants. Many fee-paying courses have expanded their interaction and networking, using social media (Networked Learning Conference, 2012). What these learning events have in common is that they are increasingly open, interaction is distributed over a wider variety of learning platforms, and they offer learners considerable autonomy and control to create their own personalised, unpredictable, and emergent learning.

Several researchers and practitioners have used aspects of complexity theory to understand these developments (Wenger, White, \& Smith 2009; Siemens \& Downes 2008, 09; Snowden \& Boone, 2007). But with the exception of Snowden, this has been rather selective. We thought it might be useful to develop a theoretical framework for emergent learning that uses complexity theory explicitly and systematically and published a paper in 2011 that attempted to do just that (Williams, Karousou, \& Mackness, 2011). It describes emergent learning as follows:

Emergent learning is likely to occur when many selforganising agents interact frequently and openly, with considerable degrees of freedom, but within specific constraints; no individual can see the whole picture; and agents and system co-evolve.

... Why is it important? Emergent learning is open and flexible, so it is responsive to context and can adapt rapidly. ...[However] emergence is not a panacea, it is an option ... it has to be integrated within an overall, inclusive learning ecology, along with prescribed learning. (p.45)

In other words, emergent learning is adaptive and, paradoxically, ordered yet unpredictable.

This paper builds on the detailed theoretical framework in the 2011 paper and focuses, instead, on developing a set of practical tools (3D footprints) to describe the relationships between emergent learning and prescribed learning and the dynamics of change across learning events within interactive social media and networks. These footprints have also been developed to be used more widely for design, strategy, and organization, that is for broader conversations about a course, for example for evaluation as well as for on-going feed-forward as the course (and even the curriculum) emerges.

In this process we re-examine the relationship between curriculum design and learning in search of adaptive organisational forms that enable emergent learning to flourish. The new curriculum can best be described as a 'topography of learning' (see Figures 2-4), or an 'architecture of participation' (Fred Garnett, 2011, personal communication). An 'emergent curriculum,' rather than being a pre-determined framework for compliance, evolves dy- 
namically during each iteration of the course (see the EBIN example). Barnett (2007) and Morrison (2007) both emphasise the rich, open opportunities such a curriculum presents, but also emphasise that these may be spaces of uncertainty, anxiety, and risk in which the students need to have the courage to be open to new experiences (Barnett, 2007, p.157).

\section{Footprints of Emergence}

\section{Developing the Emergent/Prescriptive Learning Framework}

Our 2011 paper outlined the differences between prescribed and emergent learning. Here we move on and recast these binary oppositions, instead, as overarching factors that apply across a spectrum to both prescribed and emergent learning, just in different ways, for example organization, from self-organization (emergent) to institutional organization (prescribed) (Table 2 in Appendix A).

We start with the description of a course as it was designed and presented. We are aware of the pitfalls of speculating about the intentions of the designer, so we restrict ourselves to what we know about what was actually offered. Where we have enough information, we map out the subsequent phases in the course, how the dynamics change and, crucially, whether 'agency and structure co-evolve' or, more simply, whether there is mutual adaptation and growth between the participants and the organisation of the event.

The factors that we use, such as self-organization, risk and trust, have a direct bearing on learning - but we cannot emphasise enough that each of these factors may enable or inhibit learning depending on the context - the dynamics of the situation, and the purpose of the event. None of the factors are sufficient on their own to ensure learning and, besides, to the extent that emergent learning is open and self-organised, it is always somewhat unpredictable, and in some cases the descriptions focus on how learning did not happen, when things become too risky, too close to the edge of chaos, or too prescriptive for that matter.

Every factor has an up-side and a down-side or even a dark-side. Higher education, for example, often involves 'identity workshops' (Turkle, 2012), which can be too high-risk for comfort. Barnett's spaces of uncertainty (above) can be empowering, but they can also cause anxiety. Courses that encourage students to explore their own personal narratives, for instance, can provide fascinating opportunities to explore their identities, but if not sensitively handled, they can be seriously alienating (see Williams, Karousou, \& Mallia, 2011 on the use of biographies).

In this paper we focus on just two things: 1) to determine which factors are most relevant to emergent learning and prescribed learning and the way these interact in practice; and 2) to describe the dynamics of the processes of self/organization, mapped out in three dimensional topographies of learning (Figures 2 and 4). Current terminology (e.g., VLEs or virtual learning environments) has a strong undertow of linearity and predictability. This is no longer fit for purpose to describe what Reilly (2012), for instance, talks about when 
she describes

pointillist learning [which is] the act of folding space. No longer must we progress from point A to B ... making each learner follow an identical [linear] path. Pointillist learning allows learners to determine points and fold/ unfold/refold conceptual space at will. Prediction is pointless as these types of acts ... occur in non-orientable time.

We align ourselves with theories of learning and knowledge which emphasise the role of embodied learning and knowing, multi-modal learning, and, more pertinently, cross-modal (or synaesthetic) learning, in which experience, physical engagement, and traditional cognition all play an integral part (Gumtau, 2011; Williams, Gumtau, \& Mackness, 2012). Consequently we use metaphor, and particularly visual metaphor, not as an illustrative aside but as a core mode of thinking and researching. The topography of learning is in one sense a mountain landscape, but it links to other 'topographies' too, like curved spacetime (Figure 3). However, none of these metaphors is a 'magic bullet.' This paper must be judged on its clarity and its ability to engage the mind (and more so the practices) of the reader, not on the metaphor count per page.

\section{Footprints and Topographies}

\section{Factors}

Our approach has developed through three phases. First, we tested and applied concepts which emerged from practice, participation, and research (outlined in detail in our previous paper in 2011) to our case studies to identify 25 pertinent factors. We put these factors into traditional 2D footprints, such as the 'radar' graphs in Excel (Figure 1). 


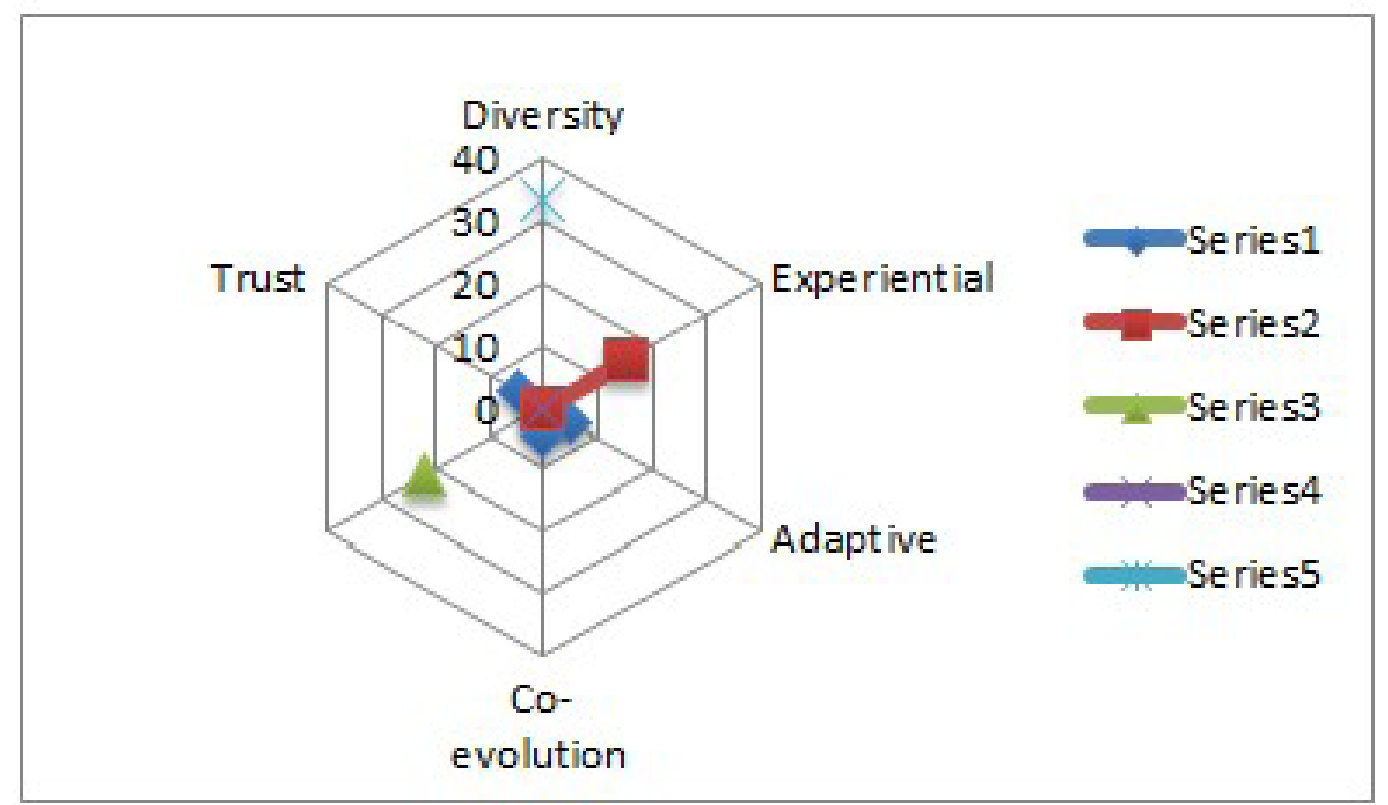

Figure 1. Radar graphs.

\section{Clusters}

We then grouped the factors into four clusters (Table 1) drawing on key elements of complexity theory, specifically the co-evolution of structure and agency (Cilliers 2005; Snowden \& Boone, 2007). The clusters are open/structure, the extent to which the overall structure of the learning 'scape is open or predetermined; interactive environment, the way openness and structure is realised in an actual event; agency, the overall extent to which agency, initiative, and identity are active elements of the learning process; and presence/writing, the way in which people present and articulate themselves and their thoughts and feelings across a wide range of media, from the immediate presence of conversation and interaction to studied, formal modes of writing. 
Table 1

\section{Clusters and Factors}

\begin{tabular}{|c|c|c|c|}
\hline \multicolumn{4}{|l|}{ Clusters } \\
\hline 1. Open / structure & $\begin{array}{l}\text { 2. Interactive envi- } \\
\text { ronment }\end{array}$ & 3. Agency & 4. Presence / writing \\
\hline Factors & Factors & Factors & Factors \\
\hline Risk & Diversity & $\begin{array}{l}\text { Cross-modal, } \\
\text { multi-modal }\end{array}$ & $\begin{array}{l}\text { Solitude and contem- } \\
\text { plation }\end{array}$ \\
\hline Liminal space & Experiential & Open affordances & $\begin{array}{l}\text { Casual encounters / } \\
\text { conversations }\end{array}$ \\
\hline Ambiguity & Adaptive & Self-organisation & $\begin{array}{l}\text { Networks encounters, } \\
\text { engagement }\end{array}$ \\
\hline $\begin{array}{l}\text { Unpredictable } \\
\text { outcomes }\end{array}$ & Co-evolution & Autonomy & $\begin{array}{l}\text { Hybrids, informal/ } \\
\text { ante-formal }\end{array}$ \\
\hline Disruption & $\begin{array}{l}\text { Frequent interac- } \\
\text { tion and networking }\end{array}$ & $\begin{array}{l}\text { Negotiated out- } \\
\text { comes }\end{array}$ & $\begin{array}{l}\text { In/formal writing and } \\
\text { inscriptions }\end{array}$ \\
\hline Self-correction & Trust & Identity & \\
\hline Multipath & Theory of mind & & \\
\hline
\end{tabular}

This arrangement of the factors in clusters gives coherence to the holistic picture of the learning 'scape and foregrounds the affordances of emergent learning. From someone else's perspective, and in another context, different factors and even different topologies might be more appropriate.

\section{D Topography}

In the conventional 'radar' footprint (Figure 1), each factor is placed on a spoke going outwards from the centre. The middle of the footprint indicates none of a particular factor, which increases outwards, with more equals high value and less equals low value. This would be a rather simplistic way to describe complexity.

Reflecting on the need to integrate prescribed and emergent learning, we realised that more of anything, even emergence, is not always a good thing. And we wanted to map out and describe the appropriate balance between prescribed and emergent learning for particular contexts, not to construct a normative and evaluative framework. So we reconfigured the footprint by replacing the vectors of a conventional (zero to max.) 'radar graphs' with factors which still vary across a spectrum, but in which there is value at both the centre and the periphery of the footprint. These range, for example, as follows: risk, high risk/to/ 
safe-to-fail /to/ fail-safe and disruption, displacing, inverting, challenging /to/ affirming, consolidating, protecting (see Table 2 in Appendix A for more details).

The centre and periphery of the footprints just deliver different kinds of value: emergence (towards the periphery) and prescription (towards the centre). The risk factor, for instance, is not about more or less risk, but rather about the different functions of risk, and the way it can be configured to enhance either emergent or prescribed learning, depending on the learning and the context. So it varies from high risk at the 'edge' of emergence (where the boundaries of learning and creativity are tested) to safe-to-fail in the middle of the emergent zone (where mistakes can be part of learning) to fail-safe in the prescribed zone (where failure is not tolerated and could even be dangerous).

These new dual-value vectors now have positive value at both ends, which means that the new topographical footprint can't be read as a conventional footprint at all. These new vectors are scored and mapped out across the underlying topography (Figures 2-4) which becomes a 3D graphic 'scaffold' for describing, discussing, and organising the learning 'scapes. The scoring method is outlined and demonstrated, with an example, in Appendix B.

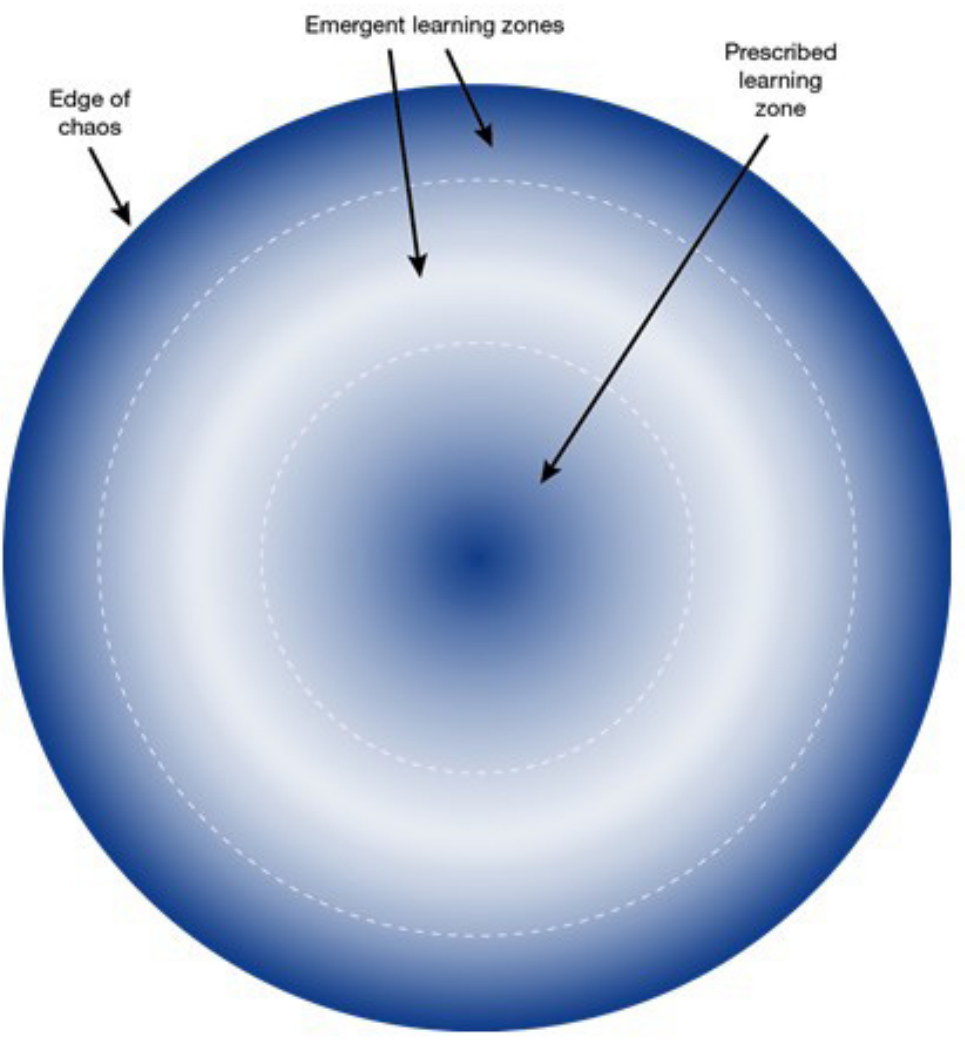

Figure 2. Topographical footprint - top view. 


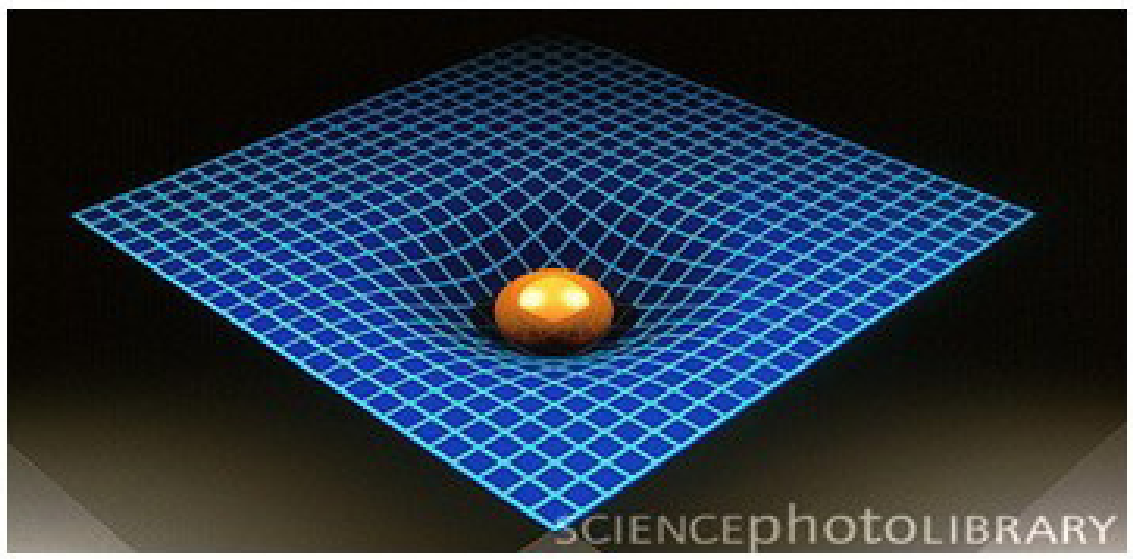

Figure 3. Curved space topography.

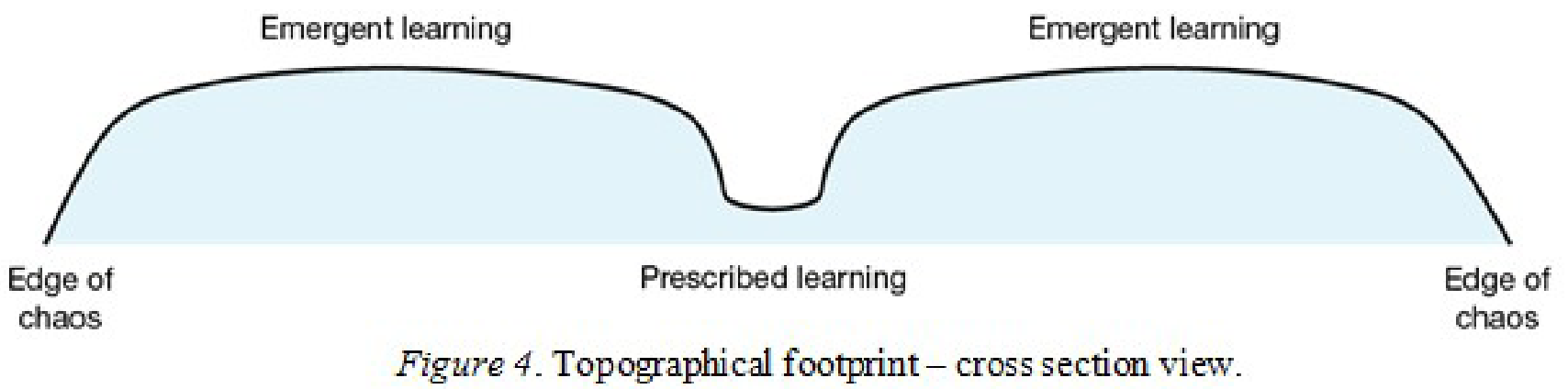

Figure 2 is a top-view of the footprint, which in perspective would look similar to the curved-space topography in Figure 3 (without the sphere of course). Figure 4 shows the topographical footprint in transverse section, or side view.

\section{Zones}

The $3 \mathrm{D}$ dynamics of the topography map out the different zones: prescribed, emergent, and chaotic, the relationships between them, and the dynamics, risks, and opportunities that are involved in moving between zones as learners choose to shift between zones or are requested to do so.

The 3D topography consists of a central (dark blue) zone of prescribed learning in which learning is low risk, stable, and organised for the learner rather than by the learner. In the topographical metaphor, this is a valley, a settlement, for reified (stable, established) knowledge. It is surrounded by a steep incline, indicating the inertia of formalised knowledge that makes this central zone difficult to climb out of, on the one hand, but safe and comfortable to 'reside' in on the other.

The top of the ridge or plateau is the second circle: the optimal zone for emergence, which 
we call the 'sweet zone,' which is off-white. It is open, inviting, ambiguous, full of possibilities, yet reasonably flat and reassuring. Around that is a further area of emergence (the third circle in a darker blue), which is increasingly higher risk, and possibly more creative, which we call 'sour' or 'sharp' emergence, depending on whether the emergence is challenging in a positive sense (sharp) or in a negative, unsettling sense (sour). Here the topography drops off sharply towards the 'edge of chaos,' where learners may fall over the cliff, get lost in social space, ensnared in the tyranny of participation, or just plain panicked. It's where emergence, interaction, and openness becomes just too much to cope with, quite counter-productive and disorientating.

The topologies of learning are not primarily concerned with the actual content of the learning. Rather, we are trying to describe the ways in which a learning 'scape is organised and experienced, dynamically, for a particular context and particular learners and whether the learning 'scape is appropriate for that context, on its own terms. Knowledge gained about emergence may provide retrospective coherence, and even a bit of wisdom, but it does not produce predictability.

\section{Palettes}

We deliberately create the footprints in a palette (Figure 5) to indicate that not all the factors apply to all the case studies. In each case we just use the factors that are appropriate, though the ones that are left behind can be as significant. 


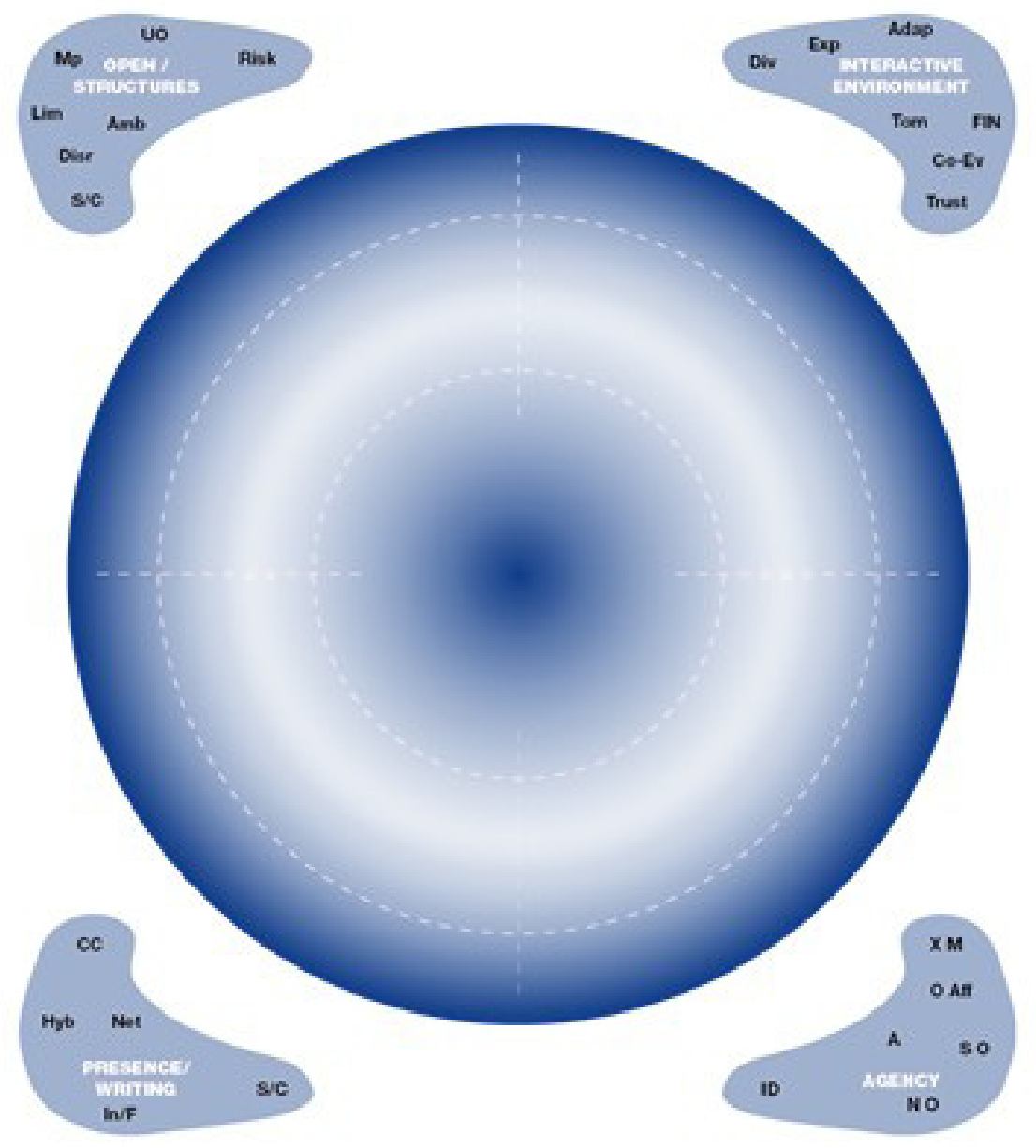

Figure 5. Palette.

When we describe a new case, we might need to add new factors to our palette just as you create and add new colours for painting. We are aware that the boundary between visual description and visual analysis is fuzzy and that creating a taxonomy is always a selective semiotic: it cuts some things in and cuts some things out. Perception and description is never innocent. Nevertheless, we try to stick to empirical, rich, graphic descriptions as far as possible.

Our palette is thus flexible and adaptive, and we use this approach to align our research with our subject matter to explore and demonstrate, graphically, what co-evolution and enactive perception means within the practice of researching. There is an onus on the reader to creatively engage with these visual descriptions.

\section{Case Studies}

The four case studies are presented here in top view only. Colour indicates the variations in depth and height across the $3 \mathrm{D}$ topography (Figures $2 \& 4$ ). The four quadrants and the 
three concentric 'zones' are clearly indicated in Figure 5, but they have been faded slightly into the background in the other footprint diagrams, to emphasise the footprint shapes. The method for 'scoring' the factors in the footprints is detailed in Appendix B.

\section{Teacher Training through Flexible Distance Learning}

A number of universities offer part-time, flexible, distance learning for primary teacher training programmes, through which students can qualify with teacher status and a PGCE.

The students in this case study differ from full-time students as they attend as few as three days face-to-face training sessions each term. Whilst away from the institution they are required to take responsibility for their own learning and manage their own time. However, online support is provided through discussion forums and opportunities for social networking by their peers, tutors, and mentors. They can nevertheless easily feel isolated.

The PGCE students follow a very broad but standards-driven curriculum (for qualified teacher status), in which there is little opportunity for negotiation or learner autonomy, and in which they are rigorously assessed. The assessment load can be very demanding. Some electives give the students opportunities for choice and increased ownership over their learning. The course is also highly practical; students learn through practice on school placements, which are also rigorously assessed.

Emphasis is placed on reflective learning both in and out of school, and students are required to keep portfolios of their work and reflective journals, which inform their practice and learning. These reflections feed into course evaluations and most courses have a student consultative group which meets with tutors. However, whilst tutors can respond to some feedback, major changes to a course can only be made through revalidation, a lengthy and complex process once every three to five years. 


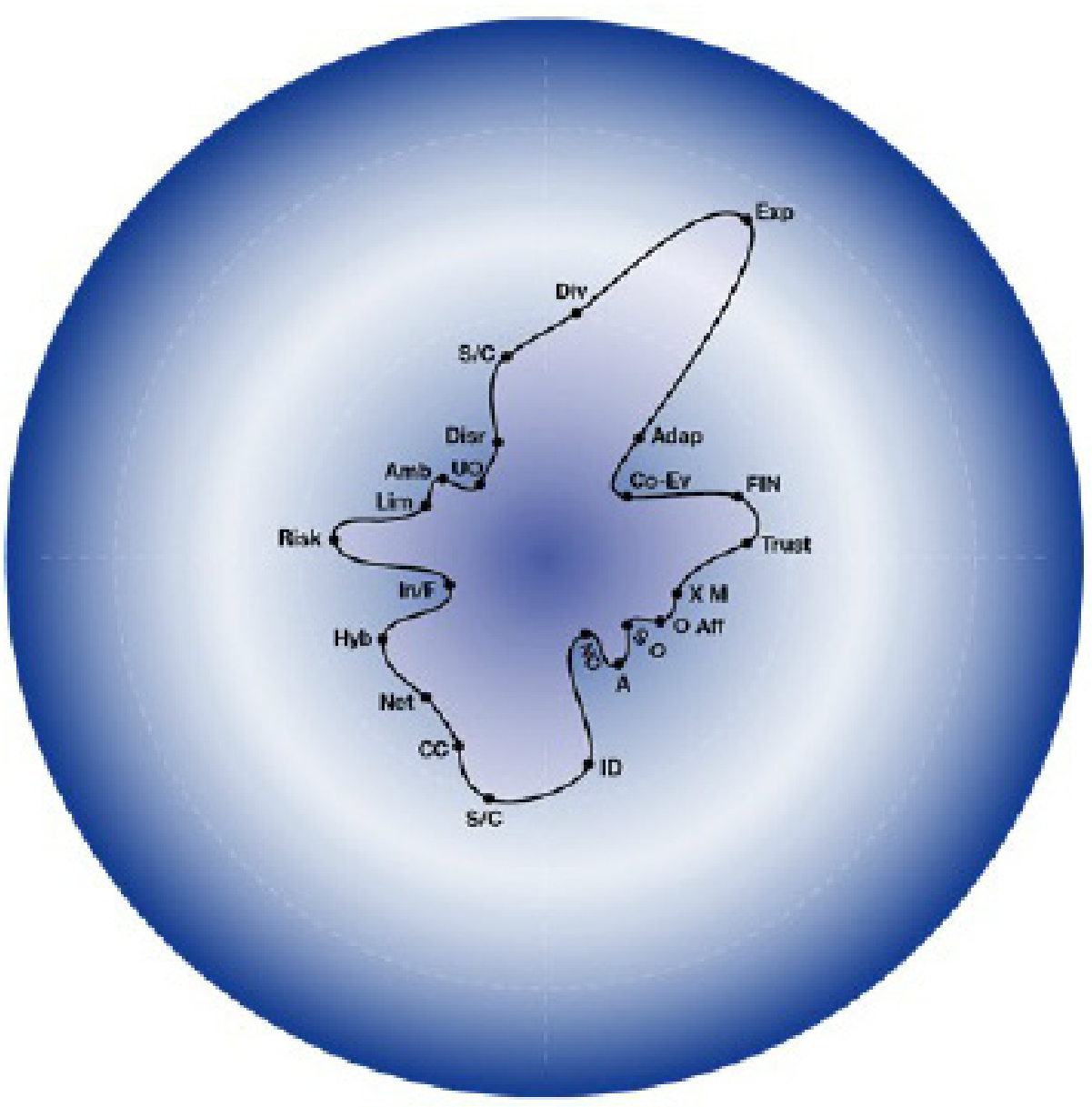

\begin{tabular}{|c|c|c|c|c|c|c|c|}
\hline \multicolumn{2}{|c|}{ OPEN/STRUCTURES } & \multicolumn{2}{|c|}{ INTERACTNEAENV. } & \multicolumn{2}{|c|}{ AOENCY } & \multicolumn{2}{|c|}{ PAESENCE_WAITING } \\
\hline REk & Flek & Chrorery & Div & $\begin{array}{l}\text { Croes-mods, } \\
\text { mwitt-modal }\end{array}$ & $x \mathrm{~m}$ & $\begin{array}{l}\text { Soltude and } \\
\text { comlempletion }\end{array}$ & $\mathbf{s} / \mathrm{c}$ \\
\hline $\begin{array}{l}\text { Uiminal space } \\
\text { (or: Ambiguty) }\end{array}$ & Lim & Experiential & Exp & $\begin{array}{l}\text { Open } \\
\text { attordenoes }\end{array}$ & OAE & $\begin{array}{c}\text { Cassal } \\
\text { Envoumers: } \\
\text { convorsations }\end{array}$ & $\infty$ \\
\hline $\begin{array}{l}\text { Anbiguily (ar: } \\
\text { Lininal space) }\end{array}$ & Amb & Adapcive & Adap & $\begin{array}{c}\text { Set. } \\
\text { orgarisation }\end{array}$ & 80 & $\begin{array}{l}\text { Notwerks } \\
\text { Encountes, } \\
\text { encagement }\end{array}$ & Not \\
\hline $\begin{array}{l}\text { Unpovedictable } \\
\text { Outosmeses }\end{array}$ & uo & Co-evolution & Co-Ev & Aularemy & A & Hytrids & Hyb \\
\hline Denuption & Dist & $\begin{array}{l}\text { Frequent } \\
\text { i-teraction and } \\
\text { Networking }\end{array}$ & FIN & $\begin{array}{l}\text { Negotated } \\
\text { Outcomes }\end{array}$ & no & $\begin{array}{l}\text { Informal } \\
\text { sriting and } \\
\text { insoriptione: }\end{array}$ & $\ln / F$ \\
\hline Dell-correction & $\mathrm{s} / \mathrm{c}$ & Truat & Truat & bently & ID & & \\
\hline Mulfpeth & Mp & Truory of Nind & Tom & & & & \\
\hline
\end{tabular}

Figure 6. Teacher training footprint and key.

\section{Masters Degree in e-Business and Innovation (EBIN)}

Lancaster University runs a unique multidisciplinary Masters degree in e-Business and Innovation (EBIN, see http://www.lums.lancs.ac.uk/masters/MScEbusiness/). This programme is jointly organised between the Management School and the Computer Science Department. It also draws on the expertise of the Institute for Entrepreneurship and Enterprise Development and the Business Enterprise Centre and Infolab21. 
The programme's approach to module design recognises the increasing functionality and complexity of the Web as an opportunity for innovation and creativity. Two modules, EBIN 521, Technology for e-Business, and EBIN 527, Software Innovation and Entrepreneurship, were designed as 'open' curricula. In the words of Dr Gerd Kortuem, module leader in 2010-2011, they "provide spaces for students to grow into."

The emphasis is on producing a new breed of innovative people who understand and are able to advance the state of the art in technical, design and business: innovative people prepared to work in challenging roles in organisation and ready to drive radical change in the digital economy.

Students are expected to see themselves as self-starters, able to create jobs, roles, and opportunities for themselves.

The open curriculum requires students to select and suggest topics for study, raise their own questions and determine what is relevant for project work and assignments, embrace the holistic cross-disciplinary curriculum, work individually and collaboratively, and be open and communicative. The aim is not only to develop students as keen critical thinkers who can demonstrate scholarship, but also as entrepreneurs who can learn and work in increasingly complex real-world environments, deal with uncertainty, spot opportunities, and make things happen. The students have considerable freedom to follow their own paths, but it is recognised that students may find this non-traditional approach challenging and unsettling. 


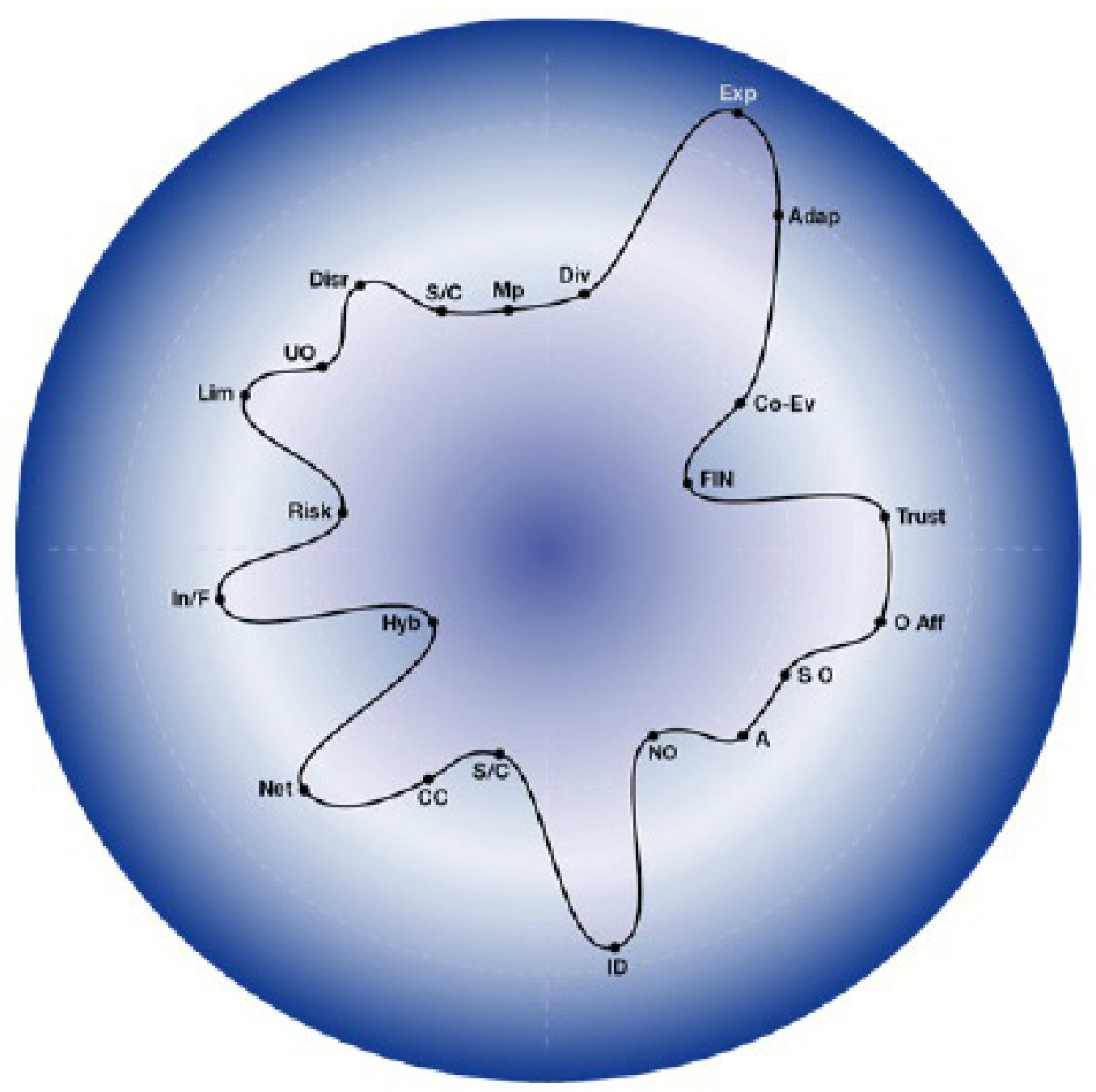

\begin{tabular}{|c|c|c|c|c|c|c|c|}
\hline \multicolumn{2}{|c|}{ OPEN/STAUCTURES } & \multicolumn{2}{|c|}{ INTEPACTIEENY. } & \multicolumn{2}{|c|}{ MGENCY } & \multicolumn{2}{|c|}{ PACSENCENWITINC } \\
\hline Rsk & Risk & Dwersily & Div & $\begin{array}{l}\text { Croes-modal, } \\
\text { multirmodal }\end{array}$ & $\times M$ & $\begin{array}{l}\text { Soltude and } \\
\text { conterplation }\end{array}$ & $\mathrm{s} / \mathrm{C}$ \\
\hline $\begin{array}{l}\text { Limindl soace } \\
\text { (or: Arbiguiv) }\end{array}$ & Lim & Experiantial & $\operatorname{Exp}$ & $\begin{array}{c}\text { Open } \\
\text { afordances }\end{array}$ & OnH & $\begin{array}{c}\text { Caevial } \\
\text { Encourtery } \\
\text { eonverantiona }\end{array}$ & $\mathrm{co}$ \\
\hline $\begin{array}{l}\text { Anbigulty for: } \\
\text { Liminal Space) }\end{array}$ & Amb & Adsptive & Adap & $\begin{array}{l}\text { Selt- } \\
\text { organisation }\end{array}$ & so & $\begin{array}{l}\text { Networks } \\
\text { Encounters, } \\
\text { engagenent }\end{array}$ & Net \\
\hline $\begin{array}{c}\text { Unpredotabie } \\
\text { Outsomes }\end{array}$ & vo & Co-evelution & Co-Ev & Autoncmy & A & Hybrids & Hyb \\
\hline Dscuption & Diar & $\begin{array}{l}\text { Froquent } \\
\text { rterection and } \\
\text { Neterorking }\end{array}$ & FIN & $\begin{array}{l}\text { Nepoliated } \\
\text { Outoomes }\end{array}$ & NO & $\begin{array}{l}\text { hormal } \\
\text { witing and } \\
\text { ineeriptione: }\end{array}$ & InF \\
\hline ses-correction & $\mathbf{s} / \mathrm{c}$ & Trust & Trust & Identhy & ID & & \\
\hline Mulfipeth & $\mathrm{Mp}$ & Theory of Mind & Iom & & & & \\
\hline
\end{tabular}

Figure 7. EBIN foctprint andkey. 
EBIN521 has been running for nine years and EBIN527 for four years. Having started with a typically traditional approach to teaching, the module leader has taken an increasingly open approach to reflect the entrepreneurial skills that the students need to develop. This is not a laissez-faire approach. Each year the course materials have been rewritten to accommodate this in response to student feedback. The module leader is constantly aware of the need to find the correct balance between guidance, structure, and openness. The modules thus demonstrate adaptability and promote emergent learning. Both students and the module leader experience the uncertainty associated of the unpredictable outcomes in an open curriculum.

The footprint for this case study shows that this programme pulls the curriculum beyond traditional, prescribed boundaries, particularly in its approach to the design of the learning environment. Whilst it embraces uncertainty and ambiguity and is highly adaptable, it attempts to limit the risks that students experience. For example the programme leader's most recent adaptation has been to somewhat constrain the degree of openness in response to student concerns.

\section{CCKo8}

This case study is based on papers by Mackness, Mak, and Williams (2010), Mak, Williams, and Mackness (2010), and Williams, Karousou, and Mackness (2011), where the CCKo8 course has been described in detail.

The Connectivism and Connective Knowledge course (CCKo8) was the first massive open online course. It was designed by Siemens and Downes to align with the characteristics of their proposed learning theory of connectivism, based on autonomy, diversity, openness, and interaction. The course ran between September and December 2008. Course participants were expected to use diverse, openly accessible resources, network with a range of participants to create their own learning paths, and organise themselves and their own learning. Through sharing of learning and resources, knowledge would be created through interaction and the artefacts produced. The design allowed for a substantial degree of emergent learning, and the outcomes could not be predicted. The course had an initial enrolment of 2,200, a much smaller number of active participants, and 24 students enrolled for formal accreditation.

The characteristics of connectivism are all evident in the footprint of the CCKo8 design, (Figure 8). There is plenty of space for openness (in the open/structure cluster), diversity (in the interactive environment cluster), autonomy (in the agency cluster), and connectivity (in the presence/writing cluster). However, the clusters in the footprints are not based on connnectivist principles, but rather on a more detailed reading of complex adaptive systems and emergence (Williams, 2011; Williams, Karousou, \& Mackness, 2011), in which the factors and dynamics are defined at a much finer level of granularity (see Appendix A \& B). 


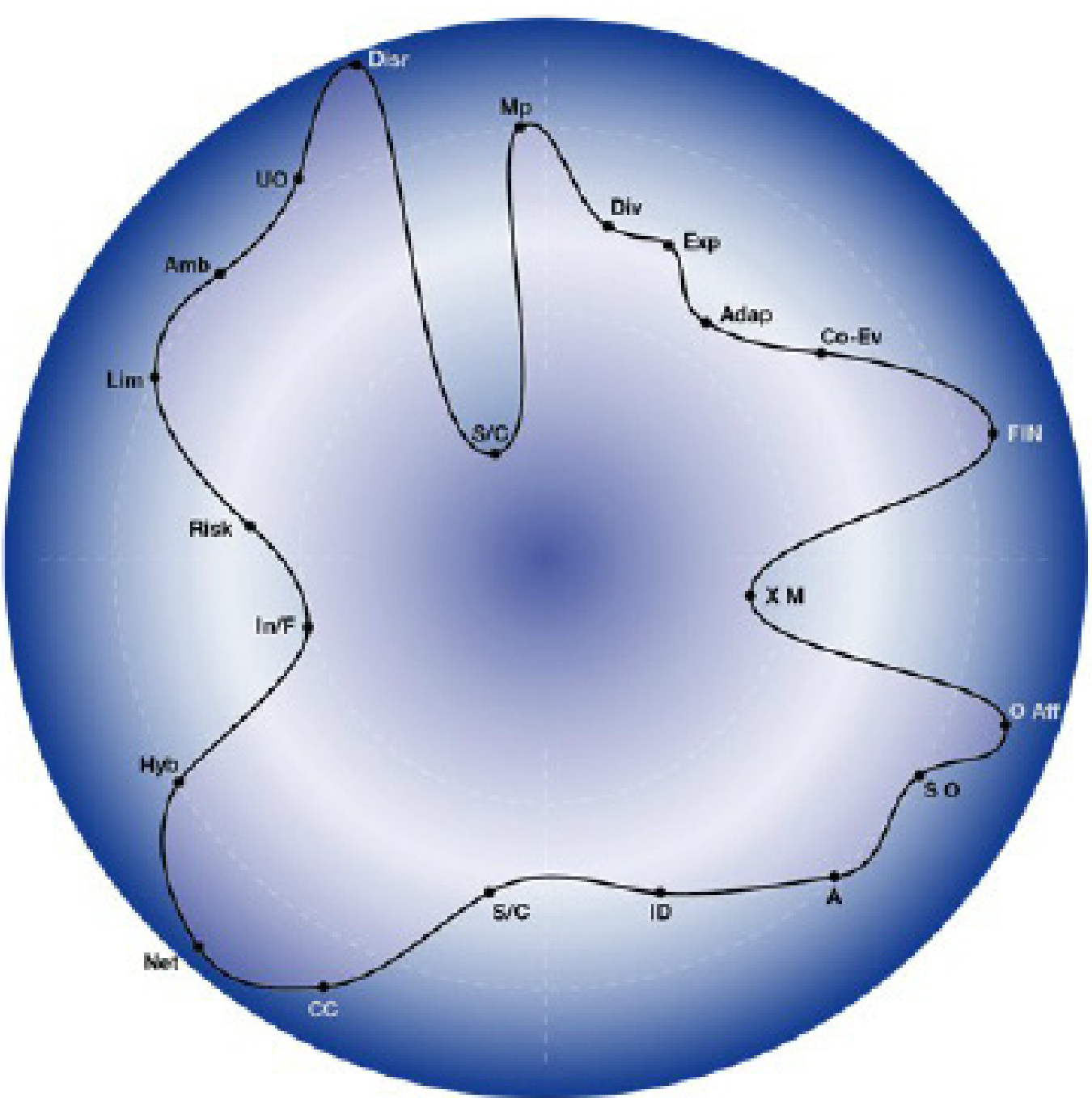

\begin{tabular}{|c|c|c|c|c|c|c|c|}
\hline \multicolumn{2}{|c|}{ OPEN/STRUCTURES } & \multicolumn{2}{|c|}{ INTERACTIVE/ENW. } & \multicolumn{2}{|c|}{ AOENCY } & \multicolumn{2}{|c|}{ PRESEMCE/WFITING } \\
\hline Fisk & Nisk & Diversity & Div & $\begin{array}{l}\text { Cross-modal } \\
\text { mutt-modal }\end{array}$ & $\mathrm{XM}$ & $\begin{array}{l}\text { Solitude and } \\
\text { contemplesion }\end{array}$ & $s / c$ \\
\hline $\begin{array}{l}\text { Uminal space } \\
\text { (or: Annbigulty }\end{array}$ & Lim & Experiential & Exp & $\begin{array}{l}\text { Open } \\
\text { allowdances }\end{array}$ & OAft & $\begin{array}{c}\text { Casual } \\
\text { Encounters } \\
\text { ocenversotions }\end{array}$ & $c c$ \\
\hline $\begin{array}{l}\text { Ambiguty (or: } \\
\text { Liminal Specel) }\end{array}$ & Amb & Adieptive & Adap & $\begin{array}{c}\text { Self- } \\
\text { organisation }\end{array}$ & so & $\begin{array}{l}\text { Narworks } \\
\text { Encouriers, } \\
\text { engegement }\end{array}$ & Not \\
\hline $\begin{array}{l}\text { Unprecictable } \\
\text { Cutconnes }\end{array}$ & vo & Co-evelition & CO-EY & Autonomy & A & Hptorids & Hye \\
\hline Disuption & Diser & $\begin{array}{l}\text { Proquort } \\
\text { Imteraction and } \\
\text { Networking }\end{array}$ & FIN & $\begin{array}{l}\text { Negotiatod } \\
\text { Otcomes }\end{array}$ & NO & $\begin{array}{l}\text { Informal } \\
\text { writng and } \\
\text { inscripilions: }\end{array}$ & In/F \\
\hline Souf-oervectisen & s/c & Truat & Trust & idortaty & ID & & \\
\hline Mulipath & Mp & Theory of Mind & Tom & & & & \\
\hline
\end{tabular}

Figure 8. CCK0 8 design and key. 
In reality, as discussed in detail in Mackness, Mak, and Williams (2010) and Williams, Karousou, and Mackness (2011), the lack of constraints in the design and the moderation of this course meant that many participants experienced some of the characteristics of emergent learning as sour and even on the edge of chaos, rather than sweet. This is evident in the way the footprints change through the course (Figure 8.1 through 8.4, and 9), as a domineering troll disrupts the course (8.1), then leaves and the course settles down (8.2), then the course designer imposes a control phase (8.3), and finally the course settles down again in the roundup phase (8.4) till the end (see the Discussion section for more details).

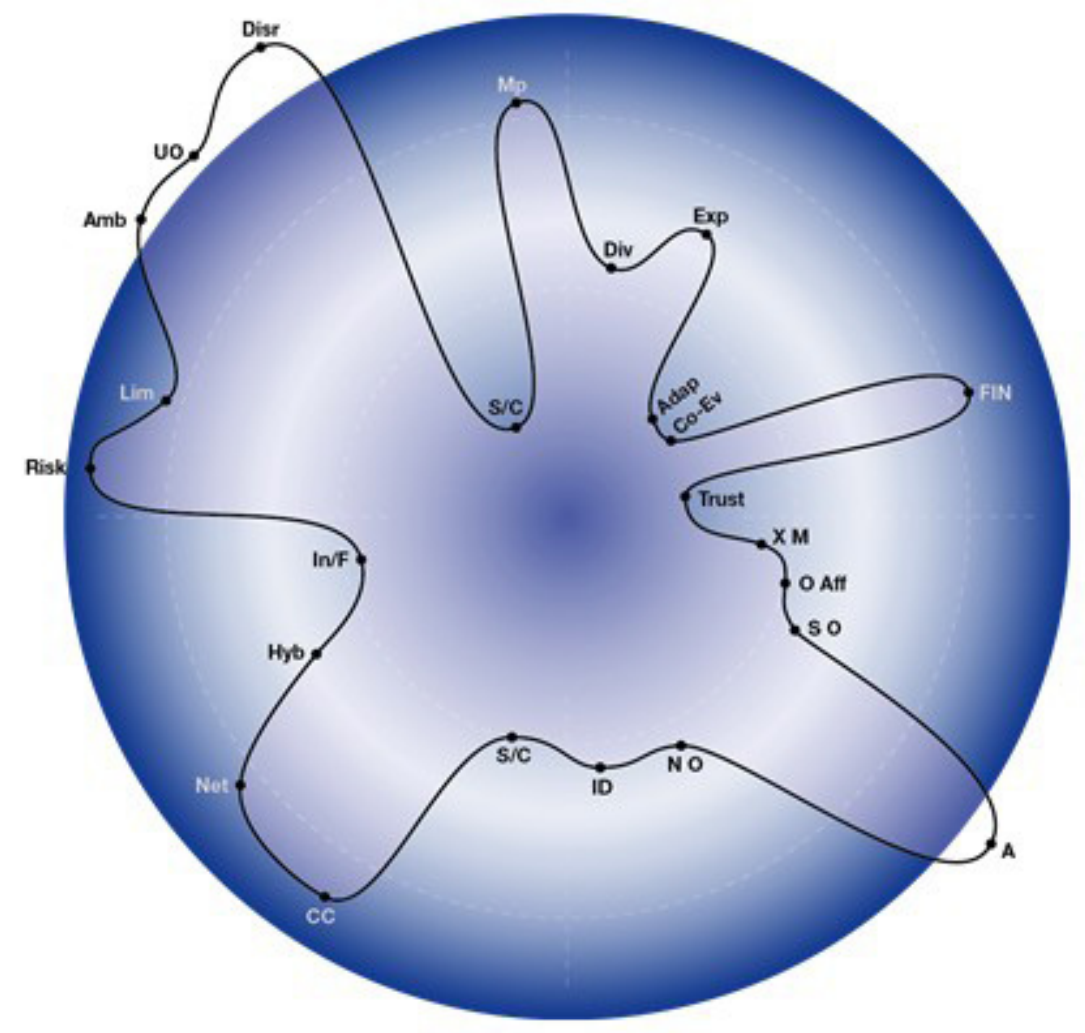

Figure 8.1. Troll phase. 


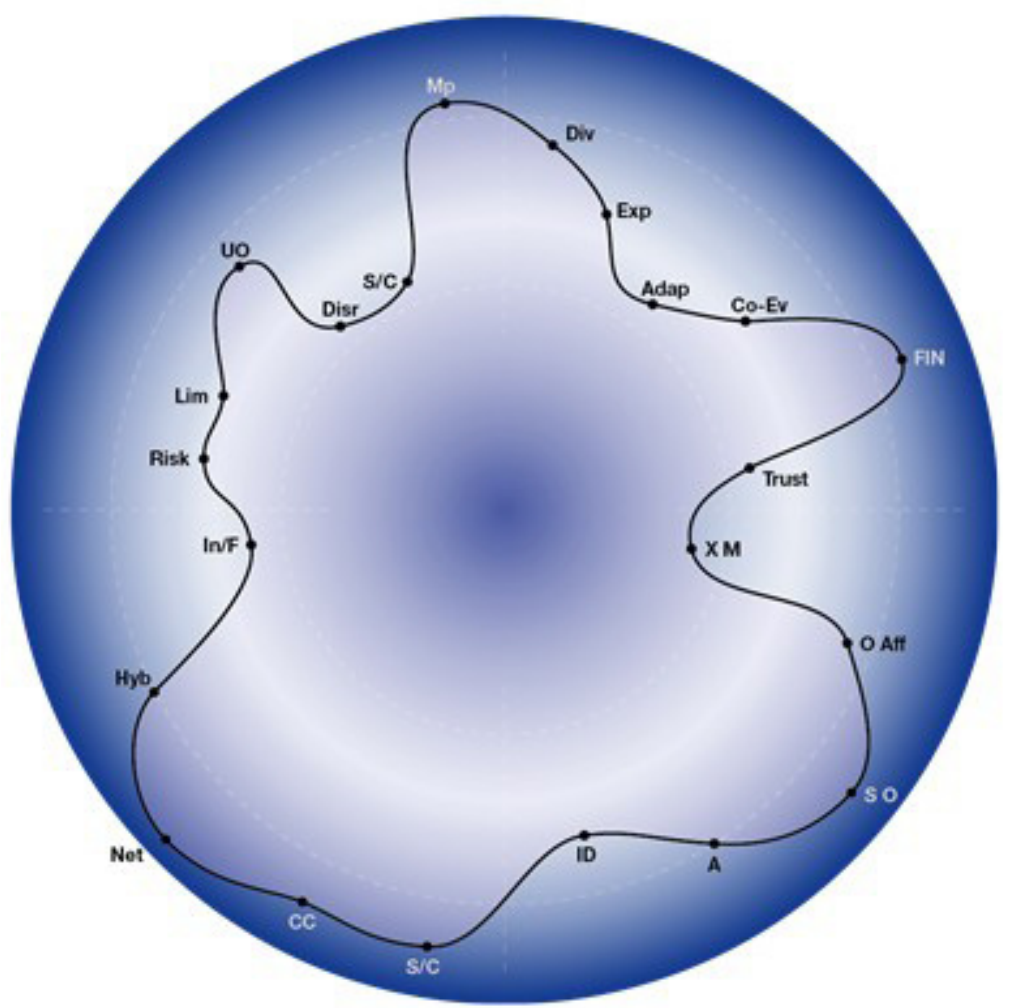

Figure 8.2. Settled phase. 


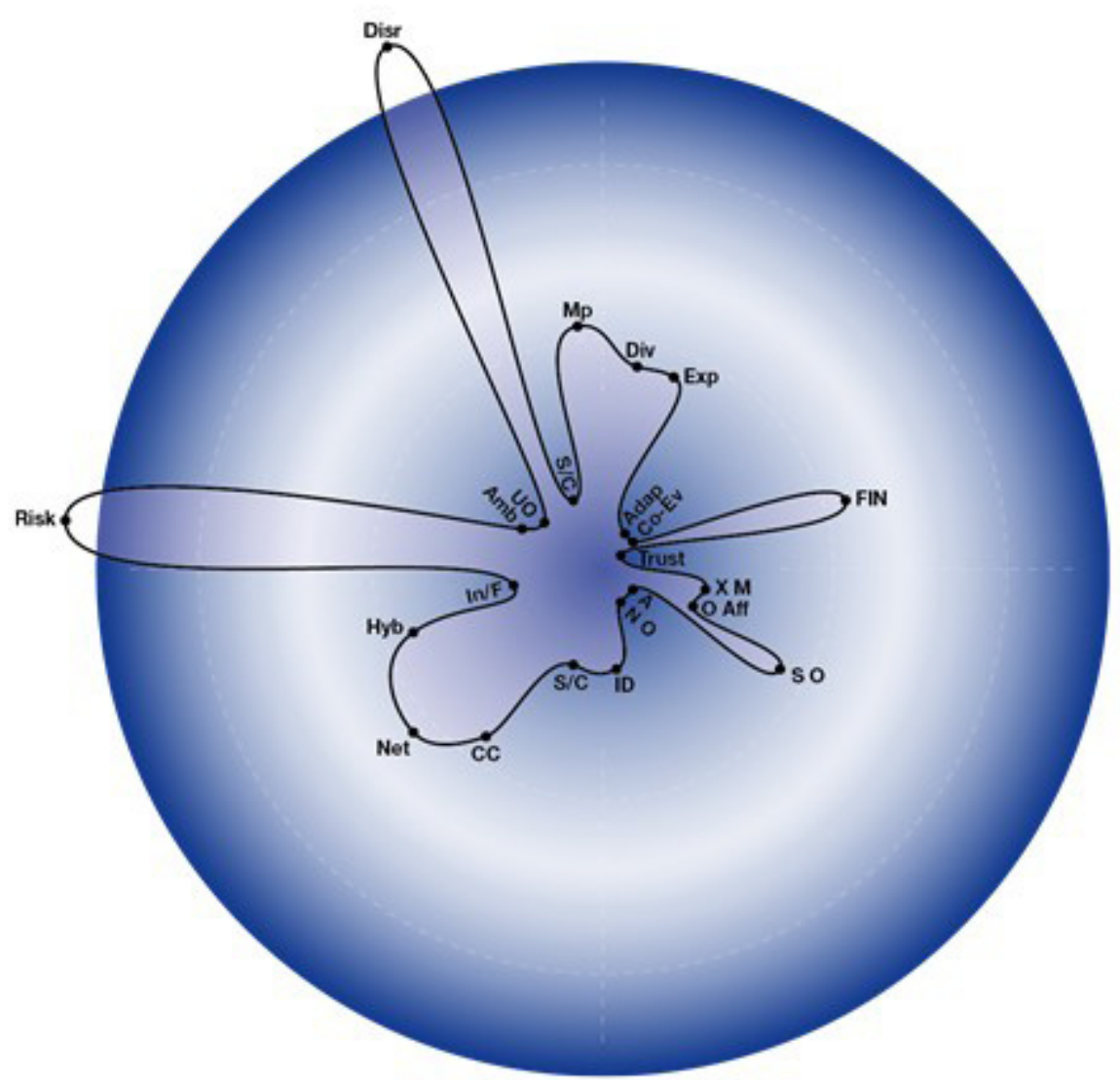

Figure 8.3. Control Phase. 


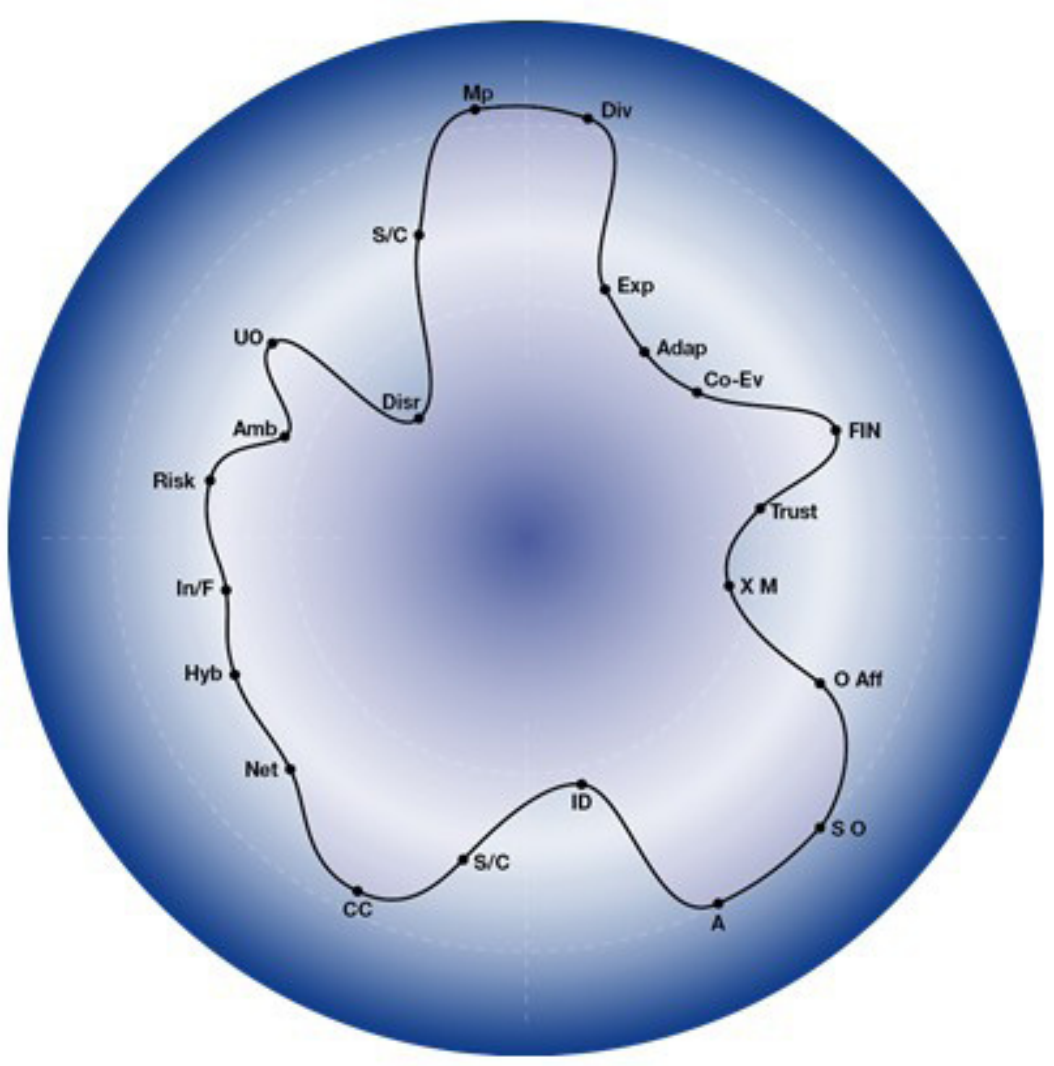

Figure 8.4. Roundup.

\section{MEDIATE}

The MEDIATE space (Multisensory Environment Design for and Interface between Autistic and Typical Expressiveness, see http://vimeo.com/15387871) was designed for so called low-functioning children on the autistic spectrum with little or no verbal skills. It was a collaboration of five teams across Europe, involving designers, programmers, and psychologists (Parés et al., 2005; Timmermans et al., 2004; Gumtau et al., 2005).

One of the design paradigms was to strive for agency (Happé, 1999; Frith \& Happé, 1999; Heaton, 1999): putting the children "in charge" of an environment that was at once rich with sensory offerings and devoid of any social context or symbolic content. Another important design paradigm was the cross-modal, or 'synaesthetic' aspect (Williams, Gumtau, \& Mackness, 2012).

The environment (Figure 9) was not designed to deliver a specific learning schedule, but rather to engage children with autism, enable them to feel in control of their space, and perhaps to play and explore areas of novelty, in behaviour, expressiveness, and agency. Through observing this dialogue, the parent or carer in turn might learn something about the child's behaviour, expressions, and sensory preferences. 


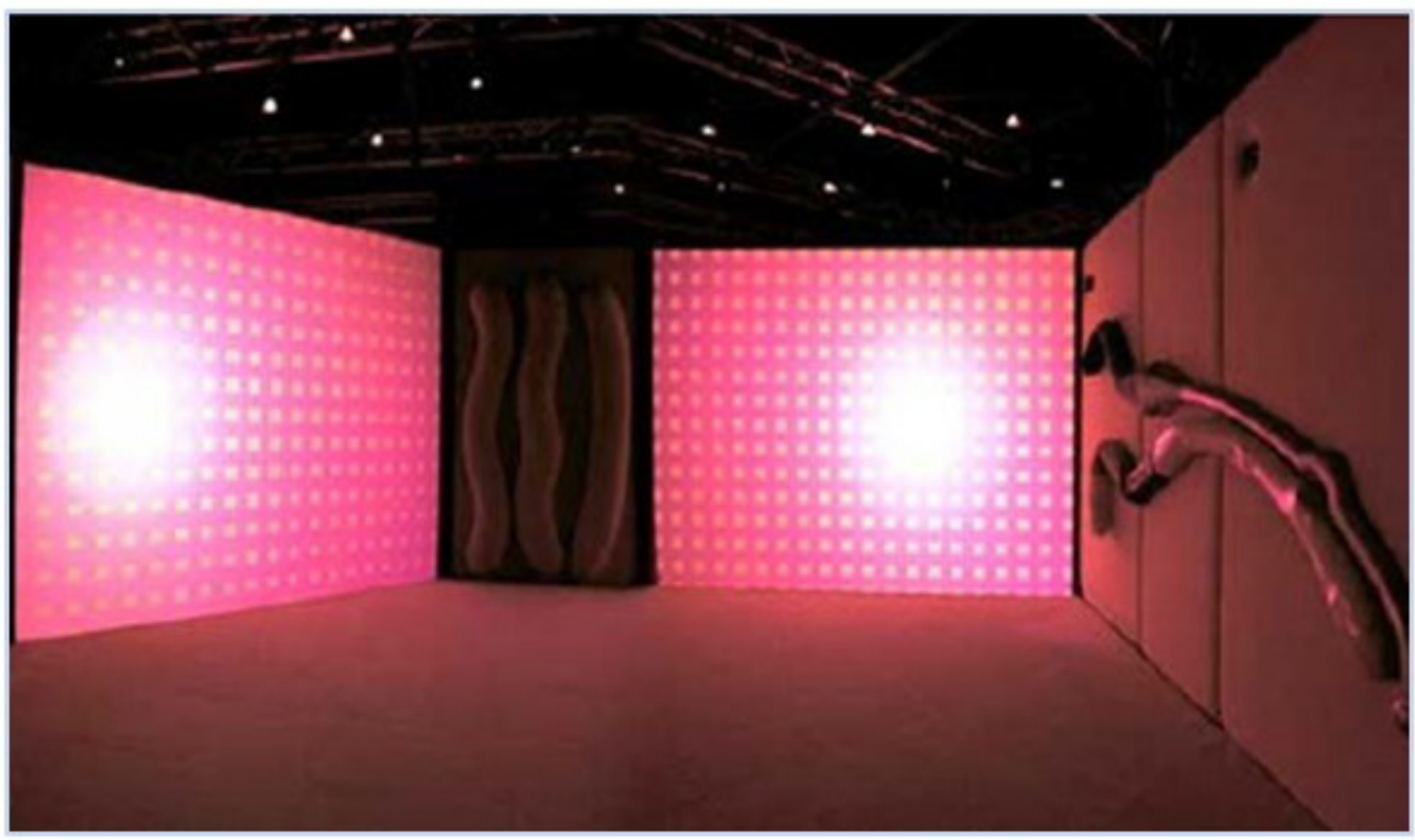

\section{Figure 9. The MEDIATE environment.}

The interactive agenda and dialogue was to be driven by the child, without instructions, so the environment had to be accessible and intuitive. The premise was to allow novel and creative behaviour and expression to emerge, and the interactive design had to move beyond predetermined, prescribed sequences.

MEDIATE was a fairly large, almost round space, which did not contain too many elements to fixate upon, but enough to experience and explore. The look and feel integrated a range of organic and haptically interesting materials and shapes and space to move around freely.

The adaptive interactive system included pattern detection software, which allowed the system to build up unique, individual sensory profiles and to identify novel idiosyncratic behaviour. The system then produced responses on the basis of whether the child was inert, fixating and repetitive, or novel and exploratory. This adaptive pattern detection and response provided a rudimentary 'mind' for the child to interact with. The challenge was to implement rules within the system that would allow for as much self-organization and adaptability as possible (Figure 10).

If the child displayed novel behaviour, the system increased the complexity of the interaction, starting off with a sensory feedback loop, or amplification of one's body. For instance, the interactive floor first produced footstep sounds, akin to walking on crunchy leaves, directly corresponding to the weight and gait of the person. After a while, the footstep's sound changed slightly into more complex and slightly more abstract responses, first a pitched 
crunch and later a singing voice. The tunefork (on the right hand wall, Figure 9) evolved similarly and was capable of cross-modality, such as a tap on the tunefork changing the colour of the screen.

The interactive design in MEDIATE starts with fairly direct feedback, and once familiarisation takes place the responses become more complex to keep the interaction interesting and encourage novel behaviour. 


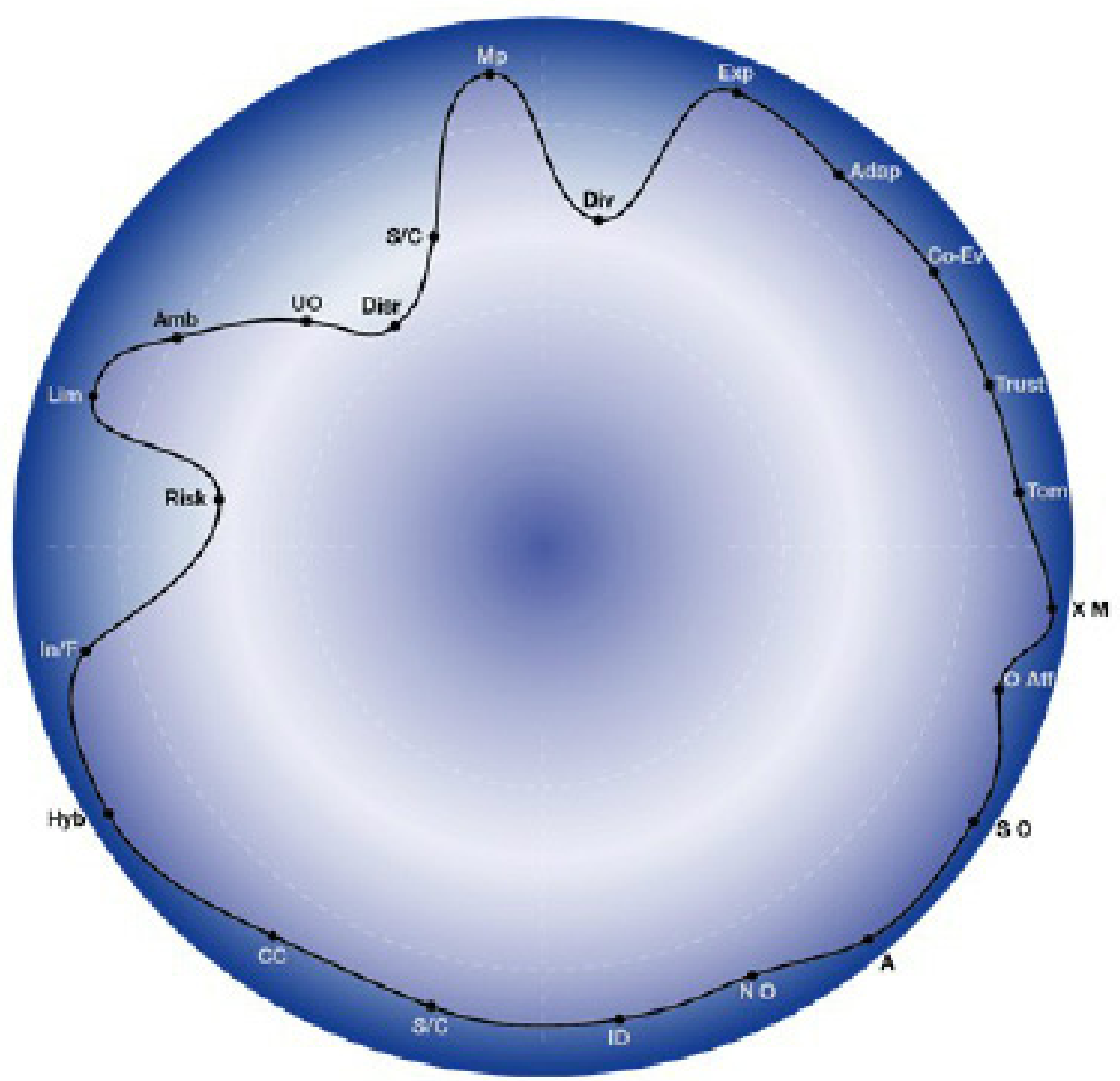

\begin{tabular}{|c|c|c|c|c|c|c|c|}
\hline \multicolumn{2}{|c|}{ OPEN/STRUCTURES } & \multicolumn{2}{|c|}{ INTERACTNEENV. } & \multicolumn{2}{|c|}{ AOENCY } & \multicolumn{2}{|c|}{ PAESENCENWRITINO } \\
\hline Pisk & Risk & Diversity & Div & $\begin{array}{l}\text { Cross-modial, } \\
\text { multi-modal }\end{array}$ & X M & $\begin{array}{l}\text { Solifude and } \\
\text { contemplaxion }\end{array}$ & $s / c$ \\
\hline $\begin{array}{l}\text { Liminal space } \\
\text { lor: Ambiguity) }\end{array}$ & Lim & Experiential & Exp & $\begin{array}{c}\text { Open } \\
\text { aflerdsnces }\end{array}$ & OAff & $\begin{array}{l}\text { Cosual } \\
\text { Encounters/ } \\
\text { comversations }\end{array}$ & $\mathrm{CC}$ \\
\hline $\begin{array}{l}\text { Ambiguity (cr: } \\
\text { Uminal Space) }\end{array}$ & Amb & Adaptive & Adap & $\begin{array}{c}\text { Self- } \\
\text { organisation }\end{array}$ & so & $\begin{array}{l}\text { Networks } \\
\text { Encounters, } \\
\text { engagement }\end{array}$ & Net \\
\hline $\begin{array}{c}\text { Unpredictable } \\
\text { Outcomes }\end{array}$ & vo & Co-evolution & Co-Ev & Autonomy & A & Hyteride & Hyb \\
\hline Disruption & Disr & $\begin{array}{l}\text { Frequent } \\
\text { Interaction and } \\
\text { Networking }\end{array}$ & FIN & $\begin{array}{l}\text { Negotialed } \\
\text { Outcomes }\end{array}$ & No & $\begin{array}{l}\text { Infiformal } \\
\text { writing and } \\
\text { inecriptions: }\end{array}$ & $\mathbf{l n} / \mathbf{F}$ \\
\hline Self-correction & sic & Trust & Trust & Identity & ID & & \\
\hline Multipath & $M p$ & Theory of Mind & Tom & & & & \\
\hline
\end{tabular}

Figure 10. MEDIATE design footprint and key. 
The MEDIATE interactive 'scape was used by a range of children, including two children we call Mr Tunefork and Mr Purple.

Mr Tunefork is a 5-year-old male without a diagnosis of autism. His visit was remarkable in that without any musical training he commandeered the sounds produced by the tunefork, a rather unusual instrument, to a high level of structured rhythm and pace. He moved up and down the bas-relief branch design, seemingly randomly touching and playing with the textures first then gradually composing a fairly complex sound-piece (Figure 10.1).

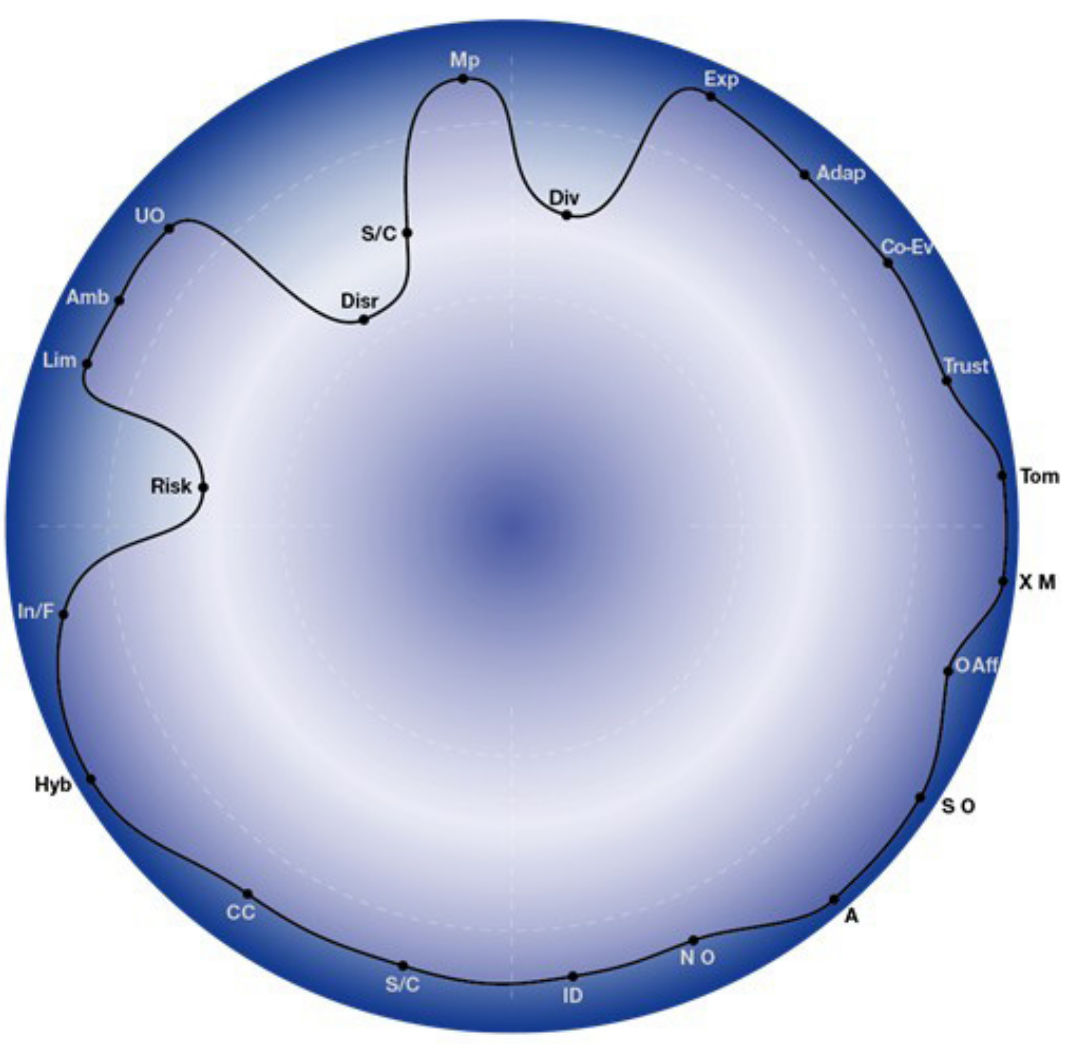

Figure 10.1. Mr Tunefork.

Mr Purple is a 9-year-old male with a diagnosis of Asperger's Syndrome, who experienced the environment at several stages. At one point the interaction level had moved to a greater complexity and thereby cross-modality, and he was able to change the colour of the screens by tapping on the tunefork. He proceeded to repeatedly select a purple hue. This might have gone unnoticed, but his mother observed it and felt that this might be a form of sensory expression that MEDIATE enabled. The family proceeded to paint his bedroom in this purple hue and consequently experienced a much calmer child, able to sleep through the night for the first time in years (Figure 10.2). 


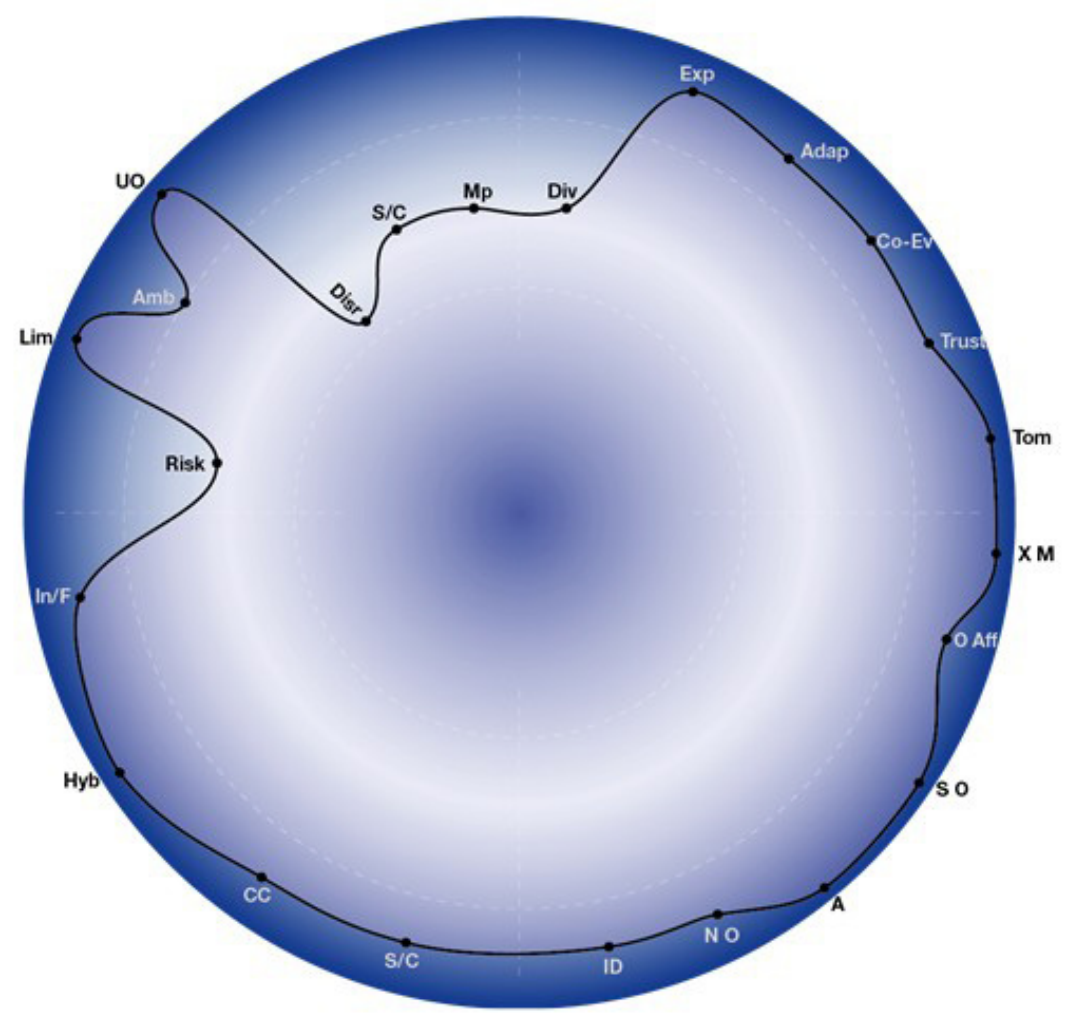

Figure 10.2. Mr Purple. 


\section{Discussion: Lessons from the Footprints}

\section{Case Studies}

The four cases vary considerably across prescribed and emergent learning (Figure 11).

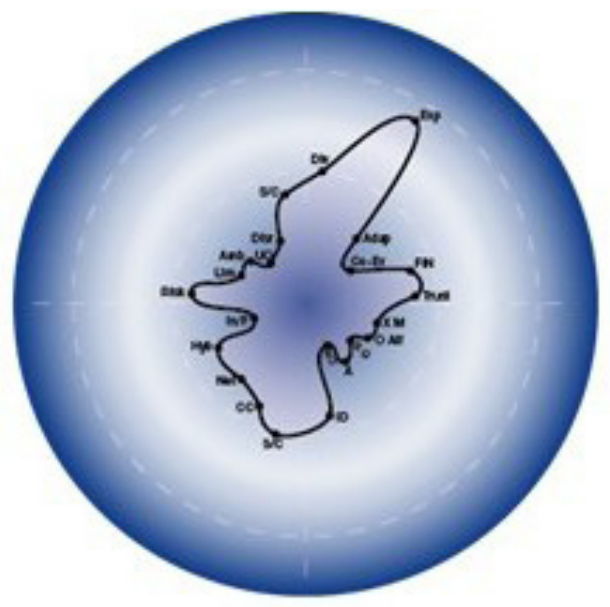

Teacher training

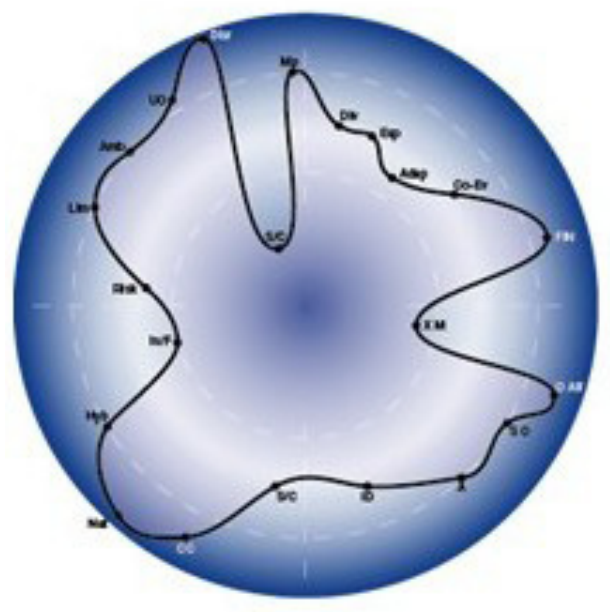

CCK08

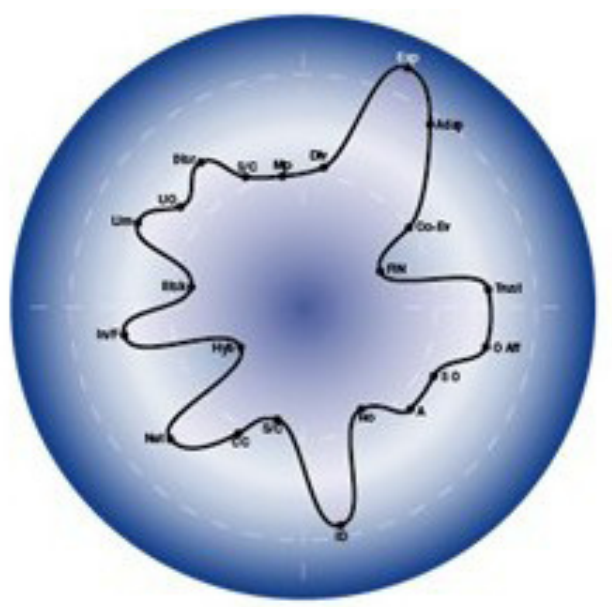

E-Business and Innovation

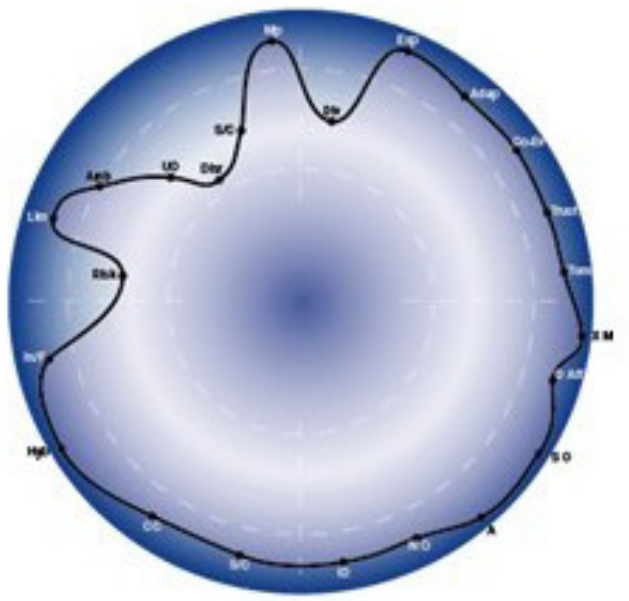

Mediate

Figure 11. Four curriculum designs. 


\section{Teacher training.}

The teacher training footprint is largely confined to the prescribed zone (Figures 6 \& 11). The teacher training course has to comply with closely defined, prescribed learning outcomes, but a few aspects of the course provided possibilities for emergent learning. The course was designed to be experiential; students were required to create their own learning spaces and be self-organised; reflective learning was encouraged for students to develop their identities as teachers. In reality the focus on compliance, stringent standards, and an over-loaded curriculum meant that there was little or no space for emergent learning. However, since the design of the programme in 2000, advances in technology have led to the students independently using social networking sites, such as Facebook and Twitter, which provide affordances for emergence.

The footprint diagram clearly indicates that all the characteristics that might lead to emergent learning (with the exception of experiential) are confined within the central, prescribed/compliance zone, which predominates. The questions for course designers are whether it is desirable to encourage emergent learning and how this can be achieved whilst meeting the required standards.

A revalidation of the programme in 2010 included new modules designed to increase reflective learning and creativity. Students are now required to arrange placements for themselves in a non-school setting, such as a museum. These modules allow greater opportunities for emergent learning, but the overall, standards-driven curriculum is still focused on prescribed skills and competencies, "so that they don't damage other people's lives" (a quote from a teacher training tutor).

\section{EBIN.}

The e-business and innovation case is substantially located in the sweet zone for emergence. Some parts are within the prescriptive zone and, like teacher training, the practical experience part of the course provides opportunities for emergent learning and requires self-organization and initiative.

The EBIN footprint shows that learner autonomy and negotiation are encouraged by the programme (Figures $7 \& 11$ ), but the extent to which they can be achieved in practice is constrained by assessment. Whilst some flexibility is built into the assessment, for example students can choose how to present their assignment and the project they wish to work on, these choices must be agreed by the programme leader before students can start work. The footprint maps out the tensions in the course between the prescriptive approach determined by the constraints of a traditional academic system and the 'sweet emergence' and 'openness' offered by the module leader's efforts to be innovative and creative. 


\section{CCKo8.}

The CCKo8 course, on the other hand, was designed as radically open and without constraint, which potentially maximised disruption of and challenges to traditional ways of learning. The risk to participants could be minimised, but only if they exercised the comparably radical degree of autonomy offered and retreated to their own spaces, such as blogs, which many participants did. Whether or not all the participants wanted to exercise such autonomy or thought it would be appropriate to do so is open to question. This may also have been affected by the extent to which the course was seen as a free-for-all as opposed to an environment in which there is mutual trust and respect.

In CCKo8 the presence of a troll (someone who deliberately disrupts the course through making inflammatory posts) in the discussion forums in the early weeks (Figures 8.1 and 12) and later a demonstration by one of the course convenors of how power can be exercised in a network (Figures 8.3 and 12) served to break down trust and respect for many participants (see Mackness, Mak, \& Williams, 2010).

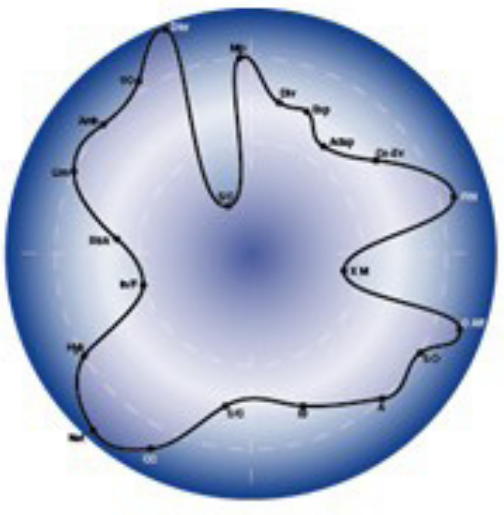

Design

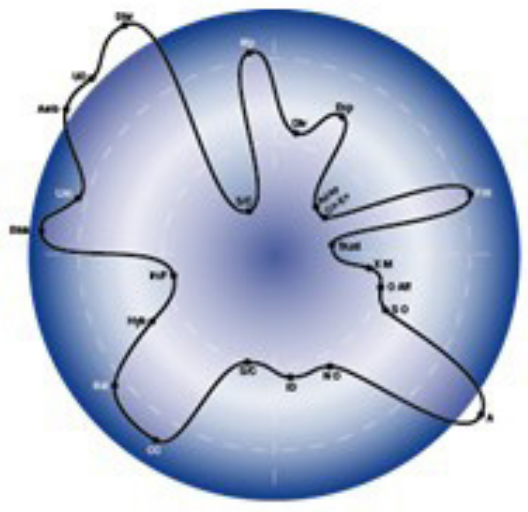

Troll

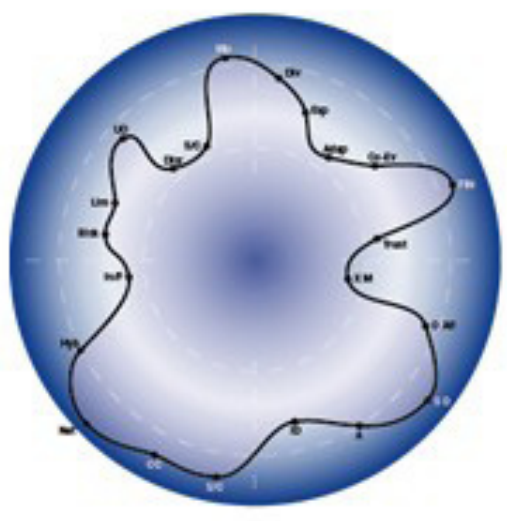

Interlude

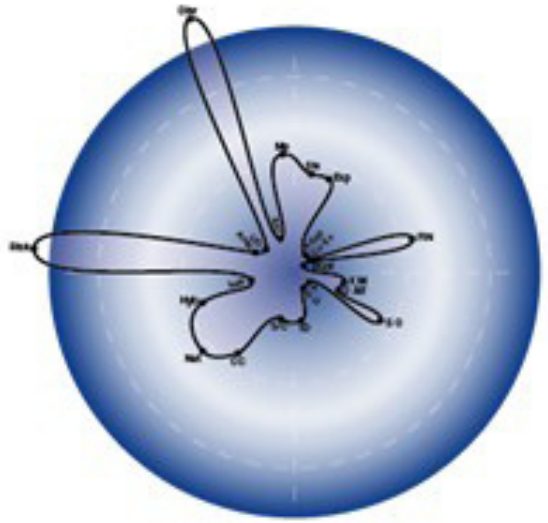

Control

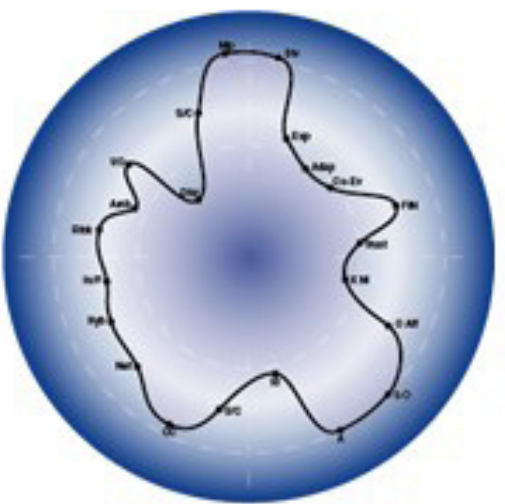

Round-up

Figure 12. The design and four phases of CCK08. 
This restructuring of the CCKo8 learning 'scape is clearly evident in the footprints (Figure 12), which contrast markedly in these two phases, in which some factors go over the edge into potential chaos. There is however an interesting contrast between the troll and control phases: in the troll phase, despite the disruption, participation continued at quite a high level in terms of the amount of interaction, although the number of participants dropped. The online interaction picked up quickly after the troll withdrew. On the other hand, although a larger number of people objected to the control intervention, there was much less interaction on any of the substantial themes of the course during this phase, and this is evident in the larger 'space' in the footprint in the troll phase compared to the control phase. The interaction did not pick up as quickly in the roundup phase that followed. Perhaps most interesting about the CCKo8 footprint is that whilst it is easily recognisable as a course which has been designed to support and promote unpredictable outcomes and emergent learning, how that is experienced by participants varied considerably. So what might be experienced as sweet emergence for some was experienced as sour or on the edge of chaos by others.

\section{MEDIATE.}

Although almost the whole MEDIATE footprint is quite close to the edge, the space was designed to provide a carefully graded approach to emergence: firstly establishing an interactive comfort zone and then moving on, step-wise, to more open interaction. This was achieved by starting with direct feedback from the body, and only once the child seemed comfortable, moving on to more complexity to keep the interaction interesting and encourage novel behaviour (Figures $10-10.2$ and 13). 


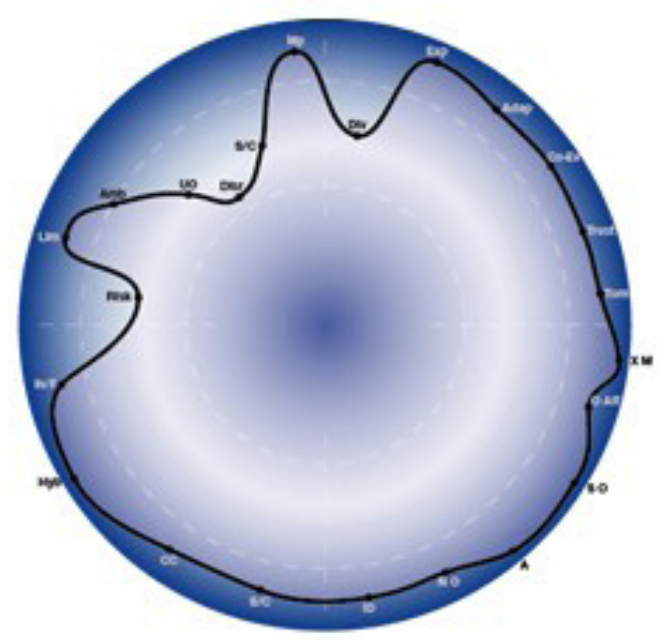

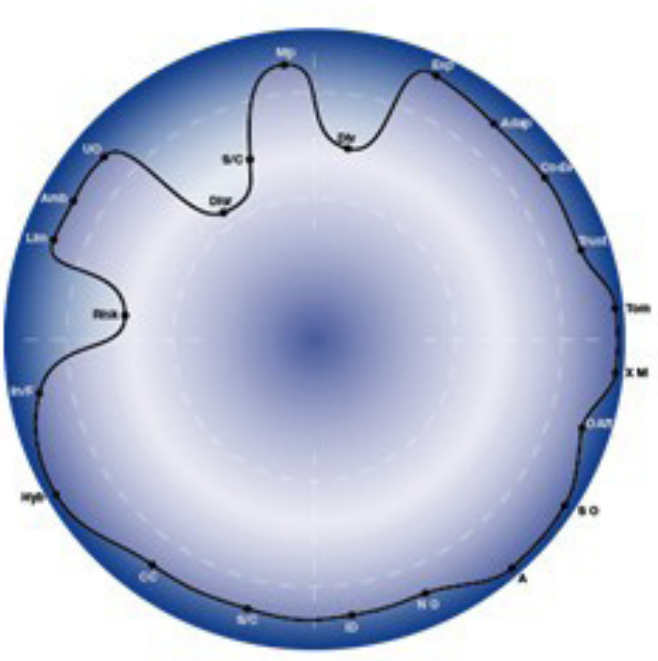

Mr Tunefork

Design

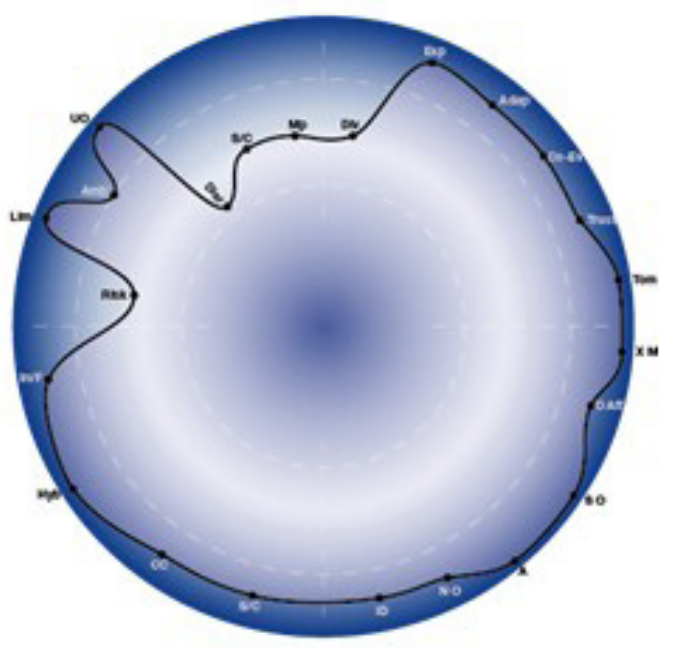

Mr Purple

Figure 13. The MEDIATE design and two participants.

Most of the children who participated in MEDIATE were on the autistic spectrum and would be expected to experience strange, dark spaces as disorientating, if not frightening. None of them did. On the contrary, they intuitively found the space to be welcoming and safe for exploration and expression, quite dramatically so. The pink colour, the soft, responsive surfaces, from underfoot to the walls, the soft lighting, and the soft, gently invitingand-challenging 'mind' all contributed to this (Figure 9).

Moreover, it was not an external 'thing' to interact with, but, on the contrary, a place to enter into, quite literally in a deeply embodied and immersive sense; it was soft, welcoming, pneumatically inviting, and responsive for the feet, the hands, the face, and the whole body. 
Within this space they found safety and comfort at a rich, encompassing, unmediated, and 'deeply synaesthetic' level.

\section{Integrating and Balancing Prescribed and Emergent Learning}

Emergent learning is by definition open, complex, adaptive, and self-organised, and therefore not predictable. The $3 \mathrm{D}$ footprints demonstrate one way to begin to describe it, across 20-25 dynamically changing parameters in a $3 \mathrm{D}$ topography. Our case studies confirm that emergent learning is indeed that rich and complex (see also Sims \& Kays, 2011).

The challenge is not to increase emergence per se, but rather to create a dynamic and appropriate balance between emergent learning and personal development on the one hand, and the necessary structure and constraint on the other hand (Williams, Karousou, \& Mackness, 2011; Cilliers, 2005). Emergent learning can all too easily slip into prescription on the one hand, or chaos on the other. The topography does not provide for a definitive analysis of all possible issues. But it does oblige you to think through the dynamics and to critically examine just how much prescription, sweet or sour/sharp emergence, and closeness to the edge of chaos is useful not just for a particular course or context, but also across different phases and for different participants.

\section{Organization}

The footprints map out how the design 'scape changes, based on the actions of the teachers and learners. In MEDIATE the participants create their own interactive footprints, which vary from the design 'scape and from those of the other participants. The MEDIATE 'scape is a finely tuned interactive space, perceived and explored differently by each participant as they establish their own affordances (Figure 13).

In CCKo8 the interventions from the course organisers dramatically changed the learning 'scape and the available affordances (Figure 9). In EBIN the design phase provided a mix of prescribed and emergent learning, but the course organiser felt that he had to provide more structure as the course progressed in response to student feedback. In the teacher training course, much of the course was prescribed learning, but work experience provided for emergent learning, and subsequent developments in the course have added to this.

The footprints cannot capture all of the rich, dynamic variety, but they do provide a multivariable template. All descriptions of complex events have to be flexible and adaptive too, to reconfigure the clusters or the underlying topography from one case, phase, or even participant to another.

\section{Designing and Curating for Emergence}

It is by definition not possible to manage emergence, but it is possible to design, curate, and organise interactive 'scapes in which emergent learning is likely to occur. The people who organise and structure the event as well as the participants must contribute to the emergence and development of the course. Both must exercise initiative, creativity, and be prepared to take some risks. For emergence to work, both structure and agency must co-evolve. 


\section{Conclusion}

The topography of learning is a rich, three dimensional visual template, which enables us to map out, describe, and explore the complex relationships and dynamics of adaptive, coevolving, ordered-yet-unpredictable learning. For the first time, perhaps, it also explicitly integrates and acknowledges the value of prescribed learning, the central repository of core knowledge. The topography provides a visual metaphor for exploring how and why learners move back and forth between the zones of prescribed learning and emergence.

Openness provides scope for creativity, emergence, and personal growth, but if pushed too far may become confusing and disorienting. The template is a practical tool for describing these dynamics: of comfort and risk, structure and agency, from fail-safe to safe-to-fail to learning on the edge, a map as well as a panopticon for emergent learning. The topography needs to be both coherent and practically useful, so it was tested in a workshop at the Future of Theory in Education Conference at Stirling University, UK, in 2012. Participants were given a short introduction to the footprints, and within an hour had drawn detailed footprints of their own courses (either as lecturers or as students). The footprints provided rich material for conversations about their courses, comparisons between courses, the dynamics of change, the balance between emergence and prescription, and how this affects the experience of the courses.

The clusters and the factors provide micro-lenses through which we can examine particular aspects and functions within the curriculum and explore the way factors vary across the emergent/prescribed spectrum and across the dynamics of a learning event. However the factors do need to be taken together; the whole is more than the sum of its parts, and the dynamics of the topography itself is a vital resource for learning and emergence.

The case studies also show that, contrary to what we know about complex emergent systems in general, emergent learning can even take place without much interaction between participants. EBIN offered the possibility of emergent learning without sustained, frequent interaction. Solitude and contemplation is an essential if unusual inclusion as a factor (in the presence/writing cluster) for this reason. In MEDIATE, emergent learning, self-organization, and co-evolution of agency is achieved by what looks like solitary learners, although the 'mind' within MEDIATE provides a sophisticated proxy for them to engage with, or, as Bateson might say, to engage in, as he saw mind as an ecology, not as discrete and individual (1972).

The presence or absence of particular factors, in itself, does not guarantee that emergent learning will occur. A sensitive and adaptive approach is required to establish and maintain co-evolution between agency and structure, organisers and participants, repetition and disruption. This was exemplified in MEDIATE.

The interactive learning 'scape as a whole is the emergent and dynamic equivalent of the traditional curriculum. This is not to say that a largely prescribed curriculum is not appropriate in particular contexts. On the contrary, the prescriptive topography of the teacher 
training course seems to have been successful on its own terms as was the radically emergent topography of MEDIATE.

The role of organising emergent learning 'scapes is an engaged curatorial role, rather than a teaching, facilitating, or even moderating one. Curating the topography of learning requires the course convenor to step back at times; it not only invites but requires self-organization, self-motivation, and creativity. This is nothing new. Montessori's approach, developed a century ago, with her focus on embodied learning and internal motivation was an exemplar of an engaged curatorial role and the co-evolution of structure and agency. The MEDIATE space could be seen as an extension of that approach (see Williams, Gumtau, \& Mackness, 2012 for a more detailed discussion of these issues).

This new topography of learning is a different kind of curriculum. No longer static, it is likely to be emergent, at least in part, even if the overall design is prescribed, and it can be specifically designed to enhance emergence. We need (at least) a 3D, multivariate framework to map out and understand the learner experience and the dynamics of how co-evolution happens over time. The footprints of emergence are one example of how this may be done, and how emergent learning can be sweet, sour or sharp, or can fall into either chaos or repetition and routine. 


\section{References}

Bateson, G. (1972). Steps to an ecology of mind. University of Chicago Press.

Barnett, R. (2007). A will to learn. Being a student in an age of uncertainty. OUP.

Cilliers, P. (2005). Complexity, deconstruction and relativism. Theory, Culture and Society, 22(5), 255-267.

Frith, U., \& Happé, F. (1999). Theory of mind and self-consciousness: What is it like to be Autistic? Mind and Language, 14(1), 82-89.

Gumtau, S., Newland, P., Creed, C., \& Kunath, S. (2005). MEDIATE. A responsive environment designed for children with autism. Accessible Design in the Digital World Conference.

Gumtau, S. (2011). Affordances of touch in multi-sensory embodied interface design (Unpublished PhD thesis). University of Portsmouth, UK.

Happé, F. (1999). Autism: Cognitive deficit or cognitive style? Trends in Cognitive Sciences, 3(6), 216-222.

Heaton, P., Hermelin, B. \& Pring, L. (1999). Can children with autistic spectrum disorders perceive affect in music? An experimental investigation. Psychological Medicine, 29, 1405-1410.

Mackness, J., Mak, Sui, Fai, J. \& Williams, R. (2010a). The ideals and reality of participating in a MOOC. In Networked Learning Conference, Aarlborg (pp. 266-274). Retrieved from http://www.lancs.ac.uk/fss/organisations/netlc/past/nlc2010/ abstracts/Mackness.html

Mak, Sui, Fai, J., Williams, R. \& Mackness, J. (2010b). Blogs and forums as communication and learning tools in a MOOC. In Networked Learning Conference, Aarlborg (pp. 275-284). Retrieved from http://www.lancs.ac.uk/fss/organisations/netlc/ past/nlc2010/abstracts/Mak.html

Morrison, K. (2007). Educational philosophy and the challenges of complexity theory. Educational Philosophy and Theory, 40(1), 19-34.

Parés, N., Masri, P., Wolferen, G., \& Creed, C. (2005). Achieving dialogue with children with severe Autism in an adaptive multisensory interaction: The "MEDIATE" Project. IEEE

Ramachandran, V.S. (2003). The emerging mind. Reith Lectures. Retrieved from: http:// www.bbc.co.uk/radio4/reith2003/

Reilly, M.A. (2012). Bold schools: Part I - Learner as Knowmad. Retrieved from http:// 
maryannreilly.blogspot.co.uk/2012/o1/bold-schools-part-i-learner-as-knowmad. html

Siemens, G., \& Downes, S. (2008, 2009). Connectivism \& connected knowledge [Online Course]. Retrieved from http://connect.downes.ca/archive/o9/12 03 thedaily. htm

Sims, R., \& Kays, E. (2011). Special issue: Emergent learning, connections, design for learning. IRRODL, 12(7). Retrieved from http://www.irrodl.org/index.php/ir$\mathrm{rodl} / \mathrm{article} /$ view/883/1686

Snowden, D.J., \& Boone, M. (2007). A leader's framework for decision making. Harvard Business Review.

Timmermans, H., Van Wolferen, G., Newland, P., \& Kunath, S. (2004). MEDIATE: Key sonic developments in an interactive installation for children with autism. Proc. Int'l Computer Music Conf.

Turkle. S. (2011). Alone together. Why we expect more from technology and less from each other. New York. Basic Books.

Wenger, E., White, N., \& Smith J. (2009). Digital habitats: Stewarding technology for communities. Portland, Oregon USA, CPsquare Press.

Williams, R. (2011). Managing complex adaptive social systems. In Encyclopedia of knowledge management ( $2^{\text {nd }}$ ed.). IGI Global.

Williams, R., Gumtau, S., \& Mackness, J. (2012, June). Synaesthesia and embodied learning. Theorising Education 2012: The Future of Theory in Education: Traditions, Trends and Trajectories Conference, University of Stirling.

Williams, R., Karousou, R., \& Mackness, J. (2011). Emergent learning and learning ecologies in Web 2.o. International Review of Research in Open and Distance Learning, 12(3). Retrieved from http://www.irrodl.org/index.php/irrodl/article/ view/883/1686

Williams, R., Karousou, R., \& Mallia, C. (2011). Narrating the self: Intersections between the public and the personal. Enhanced Learning in the Social Sciences, 3(3), 1-26. 


\section{Appendix A: Factors}

The factors and clusters that we use to create the $3 \mathrm{D}$ footprints of emergence are based on theory, research, and practice in open and networked learning. In this appendix we outline the rationale for the factors in more detail; each of the factors is italicized.

The gist of the argument (see Williams, Karousou, \& Mackness, 2011 for more detail) is that emergent behavior is the key characteristic of complex adaptive systems theory (see Cilliers, 2005; Snowden \& Boone, 2007) and is based on self-organising agents who, in the case of human culture and learning, also reflexively articulate and organize their own identity.

Emergence flourishes when agents and structure mutually co-evolve, within open affordances, autonomy, trust, and within a balance between ambiguity, disruption and wellmanaged risk (including a measure of self-correction). The outcomes are to some extent unpredictable (depending on the balance between structure and agency), but they can often be negotiated. This can provide liminal space in which personal and professional development and 'identity workshops' can take place.

Extensive interaction between the self-organising agents is generally necessary, across a range of modes, such as multi-path communication, diversity, and informal, formal, and hybrid modes of interaction (including casual communication and serendipitous encounters in a range of social media and networks). The rich interaction of experiential, crossmodal, and embodied interaction (Ramachandran, 2003), in some cases with simulated 'minds' (see MEDIATE, above), provides a rich environment for adaptive, innovative, and creative learning. And, rather surprisingly, solitude and contemplation also plays a role, although this could be seen as interaction with a proxy mind (as in MEDIATE) or with agents or texts virtually in the imagination of the person concerned. 
Table 2

Clusters and Factors

\begin{tabular}{|c|c|c|}
\hline Clusters & Factors & Spectrum of characteristics \\
\hline \multirow[t]{8}{*}{$\begin{array}{l}\text { Open/ struc- } \\
\text { tures }\end{array}$} & & The creative tension between openness and structure \\
\hline & Risk & High risk of failure $<>$ Safe-to fail $<>$ Fail-safe \\
\hline & Liminal space & Strange, transformative $<>$ Conservative, traditional \\
\hline & Ambiguity & Open to interpretation $<>$ Established meaning \\
\hline & $\begin{array}{l}\text { Unpredictable } \\
\text { Outcomes }\end{array}$ & Open to surprising outcomes $<>$ Fixed, prescribed outcomes \\
\hline & Disruption & Removing, inverting $<\ldots>$ Defending, re-establishing \\
\hline & Self-correction & Self-organised correction $<>$ Hierarchical control \\
\hline & Multipath & Many path, time and sequence options $<>$ Narrow path definition \\
\hline \multirow[t]{8}{*}{$\begin{array}{l}\text { Interactive } \\
\text { environment }\end{array}$} & & The way the open/structure (design) factors are realised and curated \\
\hline & Diversity & $\begin{array}{l}\text { A range of resources, people and perspectives }<>\text { Homogeneity, } \\
\text { standardisation }\end{array}$ \\
\hline & Experiential & Engaged, embodied, subjects $<>$ Objective, abstract, procedures \\
\hline & Adaptive & Responsive, engaging, open co-evolving $<>$ Standardised, fixed \\
\hline & Co-evolution & Mutual adaptation and growth $<>$ Fixed, hierarchical \\
\hline & $\begin{array}{l}\text { Inter-action \& } \\
\text { networking }\end{array}$ & Broad, open, networking $<>$ Bounded learning space \\
\hline & Trust & Mutual respect and growth $<>$ Competitive self-interest \\
\hline & $\begin{array}{l}\text { Theory of } \\
\text { mind }\end{array}$ & Interaction with other subjects / 'minds' $<>$ Interaction with objects \\
\hline \multirow[t]{5}{*}{ Agency } & & Developing your capability for effective action, on your own terms \\
\hline & $\begin{array}{l}\text { Cross-modal, } \\
\text { multi-modal }\end{array}$ & $\begin{array}{l}\text { Synaesthetic, embodied, holistic engagement }<>\text { Mono-modal in- } \\
\text { teraction }\end{array}$ \\
\hline & $\begin{array}{l}\text { Open affor- } \\
\text { dances }\end{array}$ & $\begin{array}{l}\text { Creative, innovative engagement }<\quad>\text { Compliance with pre-deter- } \\
\text { mined outcomes }\end{array}$ \\
\hline & $\begin{array}{l}\text { Self-organisa- } \\
\text { tion }\end{array}$ & $\begin{array}{l}\text { Organising your learning, interaction, self }-<>\text { Hierarchical organi- } \\
\text { zation }\end{array}$ \\
\hline & Autonomy & Working independently, own agenda $<>$ Working others' agendas \\
\hline
\end{tabular}




\begin{tabular}{|c|c|c|}
\hline & $\begin{array}{l}\text { Negotiated } \\
\text { outcomes }\end{array}$ & $\begin{array}{l}\text { Determining your own goals and success }<>\text { Compliance with pre- } \\
\text { scribed outcomes }\end{array}$ \\
\hline & Identity & Development of your own capability and roles $<>$ Prescribed roles \\
\hline \multirow[t]{6}{*}{$\begin{array}{l}\text { Presence / } \\
\text { writing }\end{array}$} & & $\begin{array}{l}\text { Exploring and networking the way you present yourself, your ideas } \\
\text { and feelings }\end{array}$ \\
\hline & $\begin{array}{l}\text { Solitude \& } \\
\text { contemplation }\end{array}$ & $\begin{array}{l}\text { Personal space for interaction with people, ideas, texts - in your imagi- } \\
\text { nation }<>\text { Isolation: untested ideas, individual echo-chambers }\end{array}$ \\
\hline & $\begin{array}{l}\text { Casual/ con- } \\
\text { versations }\end{array}$ & Chance, serendipitous, encounters $<>$ Highly formalised interaction \\
\hline & $\begin{array}{l}\text { Networks, } \\
\text { encounters }\end{array}$ & $\begin{array}{l}\text { Initiating and engaging in a range of networks and communities }<> \\
\text { Formalised, institutionalised interaction. }\end{array}$ \\
\hline & $\begin{array}{l}\text { Hybrids, } \\
\text { informal/ } \\
\text { ante-formal }\end{array}$ & $\begin{array}{l}\text { Choice of media and modes }<>\text { Mono-modal, mono-media, abstract } \\
\text { interactions }\end{array}$ \\
\hline & $\begin{array}{l}\text { In/formal } \\
\text { writing and } \\
\text { inscriptions }\end{array}$ & $\begin{array}{l}\text { Informal, flexible, light, interaction }<>\text { Formal, ritualised interac- } \\
\text { tions }\end{array}$ \\
\hline
\end{tabular}

\section{Appendix B: 'Scoring' the Footprints}

The footprints were created by cross-checked or consensus scoring, using what was effectively a 30-point spectrum, divided into three 10-point zones, namely prescribed, sweet, and sharp/sour emergence (the last of which was broken down further, adding an additional 'marginal' category, that is on the 'edge of chaos' (29-30), and there was also a column for scoring factors that were 'off the scale' (i.e. $31+$ ).

The scores are relational or indicative; they are not 'exact'. They were arrived at by crosschecking scoring between the authors for each of the specific footprints across phases and events within particular case studies and across case studies. The scores do not represent absolute values, but rather what we see as vectors, the degree to which a factor is pushed, pulled, squashed, drawn out, or extended towards or away from more or less prescription or emergence.

The underlying visual metaphor is of an elastic, 3D 'conceptual mat' (i.e., not a real, solid, static geological topography, but rather a 'plastic,' virtual one), which can be stretched and squashed in all three dimensions as the design and the dynamics of the 'co-evolution of structure and agency' adapt and change across a learning event. 


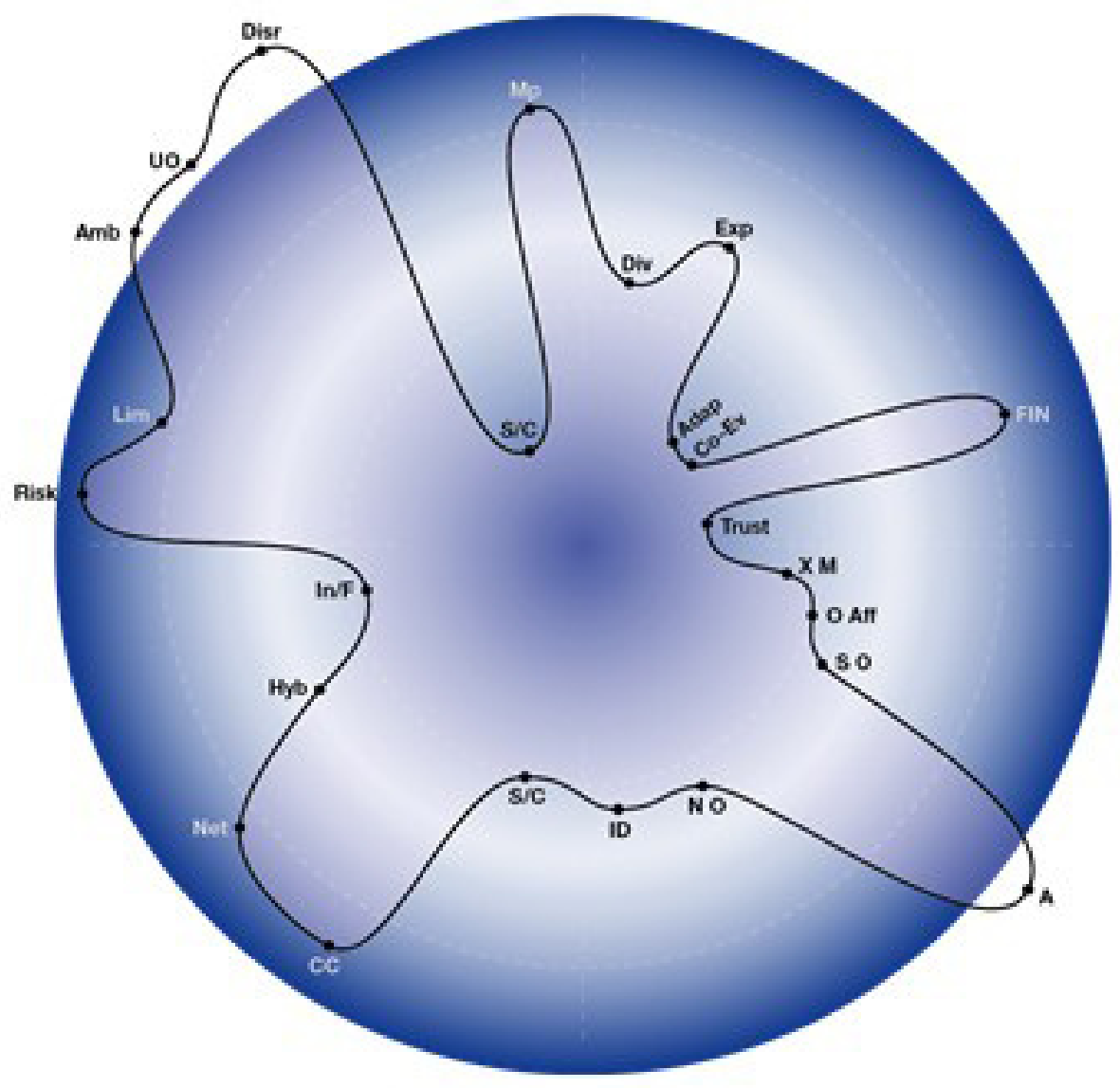

Below is an example of a score sheet ( Table $3 a$ and $3 b$, below) for the troll phase in CCKo 8 (see Figure 8.1 above in the main text). The score sheet allows for factors on the edge of chaos, as well as off the scale. These scores indicate the position of each factor on the footprint. 
Table $3 a$

The Open/Structure and Interactive Environment Clusters, Troll Phase of CCKo8

\begin{tabular}{|c|c|c|c|c|c|c|}
\hline $\begin{array}{l}\text { CCKo8: Troll } \\
\text { Phase }\end{array}$ & & $\begin{array}{l}\text { Pre- } \\
\text { scrip- } \\
\text { tive }\end{array}$ & $\begin{array}{l}\text { Sweet } \\
\text { Emer. }\end{array}$ & $\begin{array}{l}\text { Sour/ } \\
\text { Sharp } \\
\text { Emer. }\end{array}$ & $\begin{array}{l}\text { Edge } \\
\text { of } \\
\text { Chaos }\end{array}$ & $\begin{array}{l}\text { Off } \\
\text { the } \\
\text { Scale }\end{array}$ \\
\hline & & Fixed & Open & Edgy & Scary & Lost \\
\hline $\begin{array}{l}\text { Open/ struc- } \\
\text { tures }\end{array}$ & $\begin{array}{l}\text { The creative tension between openness and } \\
\text { structure }\end{array}$ & $\begin{array}{l}1 \text { to } \\
10\end{array}$ & $\begin{array}{l}11 \text { to } \\
20\end{array}$ & $\begin{array}{ll}21 & \text { to } \\
28 & \end{array}$ & $29-30$ & $31+$ \\
\hline Risk & $\begin{array}{l}\text { High risk of failure }<>\text { Safe-to fail }<> \\
\text { Fail-safe }\end{array}$ & & & & 29 & \\
\hline Liminal space & $\begin{array}{l}\text { Strange, transformative }<>\text { Conserva- } \\
\text { tive, traditional }\end{array}$ & & & 22 & & \\
\hline Ambiguity & $\begin{array}{l}\text { Open to interpretation }<>\text { Established } \\
\text { meaning }\end{array}$ & & & & & 32 \\
\hline $\begin{array}{l}\text { Unpredictable } \\
\text { outcomes }\end{array}$ & $\begin{array}{l}\text { Open to surprising outcomes }<>\text { Fixed, } \\
\text { prescribed outcomes }\end{array}$ & & & & & 32 \\
\hline Disruption & $\begin{array}{l}\text { Removing, inverting }<\ldots>\text { Defending, re- } \\
\text { establishing. }\end{array}$ & & & & & 35 \\
\hline Self-correction & $\begin{array}{l}\text { Self-organised correction }<>\text { Hierarchical } \\
\text { control }\end{array}$ & 4 & & & & \\
\hline Multipath & $\begin{array}{l}\text { Many path, time and sequence options < } \\
>\text { Narrow path definition. }\end{array}$ & & & 22 & & \\
\hline $\begin{array}{l}\text { Interactive } \\
\text { environment }\end{array}$ & $\begin{array}{l}\text { The way the open/structure (design) fac- } \\
\text { tors are realised and curated }\end{array}$ & $\begin{array}{l}1 \text { to } \\
10\end{array}$ & $\begin{array}{l}11 \text { to } \\
20\end{array}$ & $\begin{array}{ll}21 & \text { to } \\
28 & \end{array}$ & $29-30$ & $31+$ \\
\hline Diversity & $\begin{array}{l}\text { A range of resources, people and perspec- } \\
\text { tives }<>\text { Homogeneity, standardisation }\end{array}$ & & & & & 33 \\
\hline Experiential & $\begin{array}{l}\text { Engaged, embodied, subjects }<>\text { Objec- } \\
\text { tive, abstract, procedures }\end{array}$ & & 15 & & & \\
\hline Adaptive & $\begin{array}{l}\text { Responsive, engaging, open co-evolving < } \\
>\text { Standardised, fixed }\end{array}$ & 5 & & & & \\
\hline Co-evolution & $\begin{array}{l}\text { Mutual adaptation and growth }<>\text { Fixed, } \\
\text { hierarchical }\end{array}$ & 5 & & & & \\
\hline $\begin{array}{l}\text { Frequent inter- } \\
\text { action and } \\
\text { networking }\end{array}$ & $\begin{array}{l}\text { Broad, open, networking }<>\text { Bounded } \\
\text { learning space }\end{array}$ & & & 22 & & \\
\hline
\end{tabular}




\begin{tabular}{|l|l|l|l|l|l|l|}
\hline Trust & $\begin{array}{l}\text { Mutual respect and growth < > Competi- } \\
\text { tive) self-interest }\end{array}$ & 5 & & & & \\
\hline Theory of mind & $\begin{array}{l}\text { Interaction with other subjects / 'minds' < } \\
>\text { Interaction with objects }\end{array}$ & $\mathrm{n} / \mathrm{a}$ & & & & \\
\hline & & & & & & \\
\hline
\end{tabular}

Table $3 b$

The Agency and Presence/Writing Clusters, Troll Phase of CCKo8

\begin{tabular}{|c|c|c|c|c|c|c|}
\hline $\begin{array}{l}\text { CCKo8: Troll } \\
\text { Phase }\end{array}$ & & $\begin{array}{l}\text { Pre- } \\
\text { scrip- } \\
\text { tive }\end{array}$ & $\begin{array}{l}\text { Sweet } \\
\text { Emer. }\end{array}$ & $\begin{array}{l}\text { Sour/ } \\
\text { Sharp } \\
\text { Emer. }\end{array}$ & $\begin{array}{l}\text { Edge } \\
\text { of } \\
\text { Chaos }\end{array}$ & $\begin{array}{l}\text { Off } \\
\text { the } \\
\text { Scale }\end{array}$ \\
\hline & & Fixed & Open & Edgy & Scary & Lost \\
\hline Agency & $\begin{array}{l}\text { Developing your capability for effective ac- } \\
\text { tion, on your own terms }\end{array}$ & $\begin{array}{l}1 \text { to } \\
10\end{array}$ & $\begin{array}{ll}11 & \text { to } \\
20 & \end{array}$ & $\begin{array}{l}21 \text { to } \\
28\end{array}$ & $29-30$ & $31+$ \\
\hline $\begin{array}{l}\text { Cross-modal, } \\
\text { multi-modal }\end{array}$ & $\begin{array}{l}\text { Synaesthetic, embodied, holistic engage- } \\
\text { ment }<>\text { Mono-modal interaction }\end{array}$ & 8 & & & & \\
\hline $\begin{array}{l}\text { Open affor- } \\
\text { dances }\end{array}$ & $\begin{array}{l}\text { Creative, innovative engagement }<> \\
\text { Compliance with pre-determined outcomes }\end{array}$ & & 12 & & & \\
\hline $\begin{array}{l}\text { Self-organisa- } \\
\text { tion }\end{array}$ & $\begin{array}{l}\text { Organising your learning, interaction, self - } \\
<>\text { Hierarchical organization }\end{array}$ & & 15 & & & \\
\hline Autonomy & $\begin{array}{l}\text { Working independently, own agenda }<> \\
\text { Working within broader agendas }\end{array}$ & & & & & 35 \\
\hline $\begin{array}{l}\text { Negotiated } \\
\text { outcomes }\end{array}$ & $\begin{array}{l}\text { Determining your own goals and success < } \\
>\text { Compliance with prescribed outcomes }\end{array}$ & 8 & & & & \\
\hline Identity & $\begin{array}{l}\text { Development of your own capability and } \\
\text { roles }<>\text { Prescribed roles }\end{array}$ & & 12 & & & \\
\hline $\begin{array}{l}\text { Presence / } \\
\text { writing }\end{array}$ & $\begin{array}{l}\text { Exploring and networking the way you } \\
\text { present yourself, your ideas and feelings. }\end{array}$ & $\begin{array}{l}1 \text { to } \\
10\end{array}$ & $\begin{array}{ll}11 & \text { to } \\
20 & \end{array}$ & $\begin{array}{l}21 \text { to } \\
28\end{array}$ & $29-30$ & $31+$ \\
\hline $\begin{array}{l}\text { Solitude and } \\
\text { contemplation }\end{array}$ & $\begin{array}{l}\text { Personal space for interaction with people, } \\
\text { ideas, texts - in your imagination < > } \\
\text { Isolation: untested ideas, individual echo- } \\
\text { chambers }\end{array}$ & 10 & & & & \\
\hline
\end{tabular}




\begin{tabular}{|c|c|c|c|c|}
\hline $\begin{array}{l}\text { Casual encoun- } \\
\text { ters/ conversa- } \\
\text { tions }\end{array}$ & $\begin{array}{l}\text { Chance, serendipitous, encounters }<> \\
\text { Highly formalised interaction }\end{array}$ & & & 25 \\
\hline $\begin{array}{l}\text { Networks } \\
\text { encounters, en- } \\
\text { gagement }\end{array}$ & $\begin{array}{l}\text { Initiating and engaging in a range of net- } \\
\text { works and communities }<>\text { Formalised, } \\
\text { institutionalised interaction }\end{array}$ & & & 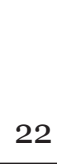 \\
\hline $\begin{array}{l}\text { Hybrids, infor- } \\
\text { mal/ ante- } \\
\text { formal }\end{array}$ & $\begin{array}{l}\text { Choice of media and modes }<>\text { Mono- } \\
\text { modal, mono-media, abstract interactions }\end{array}$ & & 14 & \\
\hline $\begin{array}{l}\text { In/formal } \\
\text { writing and } \\
\text { inscriptions }\end{array}$ & $\begin{array}{l}\text { Informal, flexible, light, interaction }<> \\
\text { Formal, ritualised interactions }\end{array}$ & 9 & & \\
\hline
\end{tabular}

\section{Athabasca University $\mathbf{A}$}

(c) 